\title{
Prostorno planiranje na području Šibensko- kninske županije od druge polovice 20. stoljeća
}

\author{
Petra Radeljak
}

\author{
Prirodoslovno-matematički fakultet, Geografski odsjek, Sveučilište u \\ Zagrebu, Hrvatska \\ e-mail: radeljak@geog.pmf.hr
}

\begin{abstract}
SAŽETAK U kontekstu preispitivanja učinkovitosti suvremenoga prostornog uređenja u Hrvatskoj te usporedbe s naslijeđem uređenja prostora koje je utjecalo na njegovo oblikovanje od druge polovice 20. stoljeća, u radu je izložen razvoj prostornoga planiranja za područje Šibensko-kninske županije (upravno-teritorijalno organizirane 1997.). Prema dostupnim izvorima rekonstruiran je slijed izrade i donošenja prostornih planova kroz tri razvojna razdoblja, te analizirani planovi višega reda prema osnovnim planskim postavkama. Prvo razdoblje trajalo je od završetka rata do sredine 1970-ih, kada je dovršena izrada prvoga republičkog prostornog plana. Drugo razdoblje trajalo je do 1992. Krajem ovoga razdoblja donesen je drugi Prostorni plan Hrvatske, a nakon stjecanja neovisnosti uveden je novi upravno-teritorijalni ustroj državnoga prostora. Treće razdoblje započelo je 1992. godine. Unutar svakoga razdoblja prepoznatljive su: makrorazina (republička/državna), mezorazina (makroregionalna i regionalna) i mikrorazina (lokalna).
\end{abstract}

Unatoč u planovima propagiranim težnjama za optimalnim i racionalnim gospodarenjem prostorom te zaštitom okoliša, na području Šibensko-kninske županije ostaje niz naslijeđenih i novih konflikata u prostoru: od problema prevelike koncentracije stanovništva i gospodarskih funkcija u priobalnim središtima, pogodovanja parcijalnim interesima i kapitalu, prevelikoga zauzimanja prostora građevinskim područjima, te objektima sekundarnoga stanovanja s velikim udjelom bespravne gradnje u priobalnom pojasu, do nedovoljno osmišljenih razvojnih alternativa. Važan mehanizam u nošenju s prostorno-razvojnim disparitetima trebalo bi biti sustavno planiranje koje će integralno promatrati prostor, a koordinacija planiranja trebala bi biti jača na (makro)regionalnoj razini. Preduvjet održivoga prostornog razvoja jačanje je prostorno-planskih službi i institucija, među ostalim stručnjacima različitih disciplina, kvalitetna izrada prostornoplanske dokumentacije interdisciplinarnom suradnjom i, nadasve, primjena planskih postavki strožim mehanizmima nadzora i sankcija.

Ključne riječi: prostorno planiranje, prostorno-planska dokumentacija, prostorno-razvojni dispariteti, Šibensko-kninska županija, Primorska Hrvatska. 


\section{Uvod}

Planiranje u prostoru podrazumijeva razmatranje razvojnih potreba i prikladnosti specifičnih mjera, funkcija i namjena površina s obzirom na obilježja određenoga područja. Ako društvo svjesno utječe na procese u prostoru, to se naziva planiranjem, a prostorni plan je nacrt kojim se određuje kako prostor najbolje koristiti u danom vremenu (Marinović-Uzelac, 2001.). U kontekstu aktualne problematike u prostoru Hrvatske nameće se potreba preispitivanja optimalnosti korištenja prostora i učinkovitosti prostornoga uređenja. Razaranja u Domovinskom ratu, uvođenje parlamentarne demokracije i prijelaz na tržišno gospodarstvo, jačanje privatnoga vlasništva, novi teritorijalni ustroj, europski integracijski procesi i globalizacija za posljedicu su imali krizu sustava vrijednosti prostornoga uređenja u Hrvatskoj te zanemarivanje zajedničkih i dugoročnih interesa u prostoru (Kranjčević, 2005.). S druge strane, otvara se pitanje usporedbe s naslijeđem uređenja prostora koje je utjecalo na njegovo oblikovanje u vremenu velikih mijena nakon Drugoga svjetskoga rata.

Planske akcije uređenja neposredne nastanjene okolice javljaju se već u starom vijeku, o čemu svjedoči pravilan raspored ulica i važnijih objekata u drevnim naseljima (Vresk, 1990.). Pretečom modernoga prostornog uređenja na području današnje Šibensko-kninske županije može se smatrati Šibenski statut, koji nastaje između 13. i sredine 16. stoljeća, kada se oblikuje i urbana fizionomija današnje povijesne jezgre Šibenika. Urbanističke odredbe u Statutu odnose se na propise o izgradnji i popravku zgrada, kao i odredbe o javnom redu i gradskoj higijeni (Zelić, 1995.). U prvoj četvrtini 14. stoljeća nastao je i Statut grada Skradina, povijesno i geografsko vrelo koje daje okvirnu sliku o društveno-ekonomskim značajkama, ustroju i pravnom sustavu Skradina 14. stoljeća, a tek poneka odredba odnosila se na uređenje prostora ${ }^{1}$.

Za razliku od lokalne razine, planiranje na regionalnoj i nacionalnoj razini mlada je društvena djelatnost, čija se institucionalizacija na zakonodavnim osnovama javlja tek između dva svjetska rata, odnosno, u većini zemalja, nakon Drugoga svjetskog rata (Vresk, 1990.). Razvoj poslijeratnoga planiranja u Hrvatskoj pratila je odgovarajuća zakonodavna osnova, koja je, među ostalim, propisivala vrste prostornih planova koje su izrađivane na svim razinama - od republičke/državne, preko makroregionalne i regionalne, do lokalne razine.

Poseban interes i osnovni prostorni okvir ovoga istraživanja čini područje Šibenskokninske županije (upravno-teritorijalno organizirane 1997.). Radi se o prostoru koji je, kao i Primorska Hrvatska u cjelini, od druge polovice 20. stoljeća u velikoj mjeri funkcionalno i fizionomski preobražen. Procesi litoralizacije, odnosno urbano bazirane industrijalizacije i turističkoga razvoja uvjetovali su koncentraciju stanovništva i ekonomske aktivnosti u obalnim središtima, praćenu deagrarizacijom i deruralizacijom, odnosno depopulacijom i društveno-gospodarskim zaostajanjem zaleđa i većega dijela otočkih naselja (Defilippis, 2006.; Faričić, Graovac i Čuka, 2010.; Nejašmić,

1 Radi prolaza se ima “... jedan korak kako od zida graditi, tako od vinograda ili zemlje ili polja mjeriti." (Statut grada Skradina, LXX, 2002.:210). 
1991.; Šimunović, 1982.). Više autora bavilo se razvojem prostornoga planiranja u pojedinim područjima primorske Hrvatske. Primjerice, Hrvatin i Grgurević (2007.) prikazali su kontinuitet izrade prostornih planova različitih razina i prostornih obuhvata u zapadnoj Istri - nekadašnjim općinama Rovinj, Poreč i Buje od sredine 1960-ih. Ukazali su na postojanje stajališta o potrebi usmjeravanja razvoja, izgradnje i uređenja prostora putem prostornih planova. Međutim, novom administrativnom podjelom s 18 općina/gradova izrada, donošenje i realizacija planova postala je složenija. Marić (2009.) obrađuje značajke i posebnosti prostornoga planiranja u Dubrovačko-neretvanskoj županiji u posljednjih 60-ak godina te zaključno ukazuje na probleme kvalitetnoga i održivoga prostornog planiranja.

Iz potrebe preispitivanja učinkovitosti prostornog uređenja i optimalnosti korištenja prostora te usporedbe naslijeđa prostornoga planiranja u Hrvatskoj nakon Drugoga svjetskog rata u odnosu na recentno razdoblje proizlazi svrha te osnovni cilj ovoga rada: usporediti obilježja prostornoga planiranja kroz tri osnovna razdoblja, s obzirom na razvojne procese i preobrazbu područja Šibensko-kninske županije. Zadaci rada su stoga: analizirati zakonodavni okvir prostornoga planiranja u Hrvatskoj prema propisanim dokumentima prostornoga uređenja, rekonstruirati slijed izrade i donošenja prostornih planova za područje Šibensko-kninske županije, prikazati osnovne postavke planova višega reda (kako bi se ukazalo i na razvojne trendove) i obilježja planiranja.

Prostorno-planska dokumentacija prikupljena je iz arhiva planerskih tvrtki i zavoda za prostorno uređenje (URBING d.o.o., Urbanistički institut Hrvatske d.d., Zavod za prostorno uređenje Šibensko-kninske županije), knjižničnoga fonda Središnje geografske knjižnice Geografskoga odsjeka PMF-a u Zagrebu, sveučilišnih knjižnica u Zagrebu i Splitu², te mrežno dostupne dokumentacije.

S obzirom na dostupne izvore slijed izrade i donošenja prostornih planova ${ }^{3}$ tablično je prikazan, a planovi višega reda su analizirani prema osnovnim planskim postavkama (pri čemu je važna i ocjena odnosa prema prostornim procesima i strukturama u prethodnom razdoblju). Posebno zanimanje usmjereno je na sustav središnjih naselja ili razvojnih žarišta (urbani sustav), budući da se njime teži usmjeravanju prostornoga rasporeda stanovništva, potiče razvoj optimalne mreže naselja (usmjeravanjem gospodarskih djelatnosti i urbanotvornih funkcija) te podržava razvoj ostalih gradskih i ruralnih naselja koja za to imaju preduvjete (Strategija prostornoga uređenja Republike Hrvatske [SPURH], 1997.).

2 Na susretljivosti i pružanju uvida u arhivsku građu autorica im se posebno zahvaljuje.

3 Budući da nije bilo moguće dobiti uvid u svu prostorno-plansku dokumentaciju izrađenu za područje Šibensko-kninske županije nakon Drugoga svjetskog rata te da je u razdoblju od nekoliko desetljeća dio dokumentacije i zagubljen ili stradao u Domovinskom ratu (posebno u slučaju bivših općina Drniš i Knin), moguće je da je neki od planova u slijedu izostavljen. Također, u slijedu je naznačeno ako se nije moglo sa sigurnošću utvrditi točno vrijeme izrade ili donošenja planova, s obzirom na ograničenja ili proturječnosti u izvorima. 
Prema trendovima u prostornom uređenju na republičkoj/državnoj razini koji su se odrazili i na ovaj prostor, nakon Drugoga svjetskog rata izdvojena su tri osnovna razvojna razdoblja planiranja za područje Šibensko-kninske županije. Prvo razdoblje trajalo je od završetka rata do sredine 1970-ih, kada je dovršena izrada prvoga republičkog prostornog plana. U primjeni je bio i novi Zakon o prostornom uređenju iz 1973. Drugo razdoblje trajalo je do 1992. godine. Krajem ovoga razdoblja donesen je drugi prostorni plan Hrvatske, a nakon stjecanja neovisnosti uveden je novi upravno-teritorijalni ustroj. Treće razdoblje započelo je 1992. Unutar svakoga razdoblja prepoznatljive su tri razine: makrorazina (republička/državna), mezorazina (makroregionalna i regionalna) te mikrorazina (lokalna). Lokalnom razinom smatrani su planovi izrađivani na općinskoj razini, a u slijedu su navedeni planovi do razine provedbenih planova (PUP/DUP, PUMN, UPU, DPU).

Zaključno se ocjenjuje učinkovitost prostornoga planiranja na području Šibenskokninske županije.

\section{Prostorni okvir istraživanja}

Današnja Šibensko-kninska županija dio je sjeverne Dalmacije, u dodirnom prostoru prema srednjoj Dalmaciji. Povoljna obilježja njenoga geografskoga položaja označavaju komunikacijski pravci koji se križaju na ovom području - to su jadranski dužobalni pravac te poprečni pravac Šibenik - Drniš - Knin, koji se nastavlja prema unutrašnjosti, tj. kontinentalnom zaobalju.

U funkcionalno-prostornom smislu Županija čini šibensku regiju, koja se sastoji od šibenske (u užem smislu), drniške i kninske subregije. U razdoblju nakon Drugoga svjetskog rata ovakvi prostorni odnosi praćeni su uglavnom odgovarajućom upravno-teritorijalnom podjelom. Prije i nakon rata bio je formiran šibenski okrug s tri kotara (šibenski, drniški i kninski). Uglavnom isti prostor zatim je bio obuhvaćen velikim šibenskim kotarom (općine Šibenik, Drniš i Knin) 1953. - 1961., a potom s tri proširene općine (Friganović, u: Geografija SR Hrvatske, Južno Hrvatsko primorje, 1974.). Model velikih općina uveden u Hrvatskoj 1962. (s kasnijim manjim izmjenama) uvelike je odražavao načela centralizacije. Osobito u siromašnijim i izoliranijim krajevima velike općine označile su koncentraciju i polarizaciju moći i sredstava u glavnim središtima, što je bilo popraćeno jačim siromašenjem rubnih prostora, ruralnim egzodusom, napuštanjem malih otoka, planinskih i gorskih zona, rastom broja stanovnika u gradovima, svojevrsnom "ruralizacijom" gradova (Magaš, 2000.).

Već 1961. - 1991. glavnina područja Županije depopulira - ima negativnu migracijsku bilancu. Pritom su izražene prostorne razlike: drniški kraj postajao je sve izrazitiji prostor depopulacije $\mathrm{s}$ trendom $\mathrm{k}$ izumiranju u međupopisnom razdoblju 1981.1991., kninski kraj sputavao je izrazitu depopulaciju, dok je samo šibenski dio regije imao pozitivnu migracijsku bilancu 1980-ih. Stiješnjenost i stanovito zaostajanje u populacijskoj dinamici uvjetuje i smještaj šibenske regije između dviju dinamičnijih regija, zadarske i splitske (Friganović, 1992.). 
Tijekom i nakon Domovinskoga rata teritorij Republike Hrvatske preuređen je u sustav županija, gradova i općina. Krajem 1992. osnovana je Županija Šibenska koja je obuhvaćala bivše općine Drniš i Šibenik, a reorganizacijom 1997. konačno je uređena Šibensko-kninska županija. Prema trenutno važećem Zakonu o područjima županija, gradova i općina u Republici Hrvatskoj (NN 86/06) Šibensko-kninska županija obuhvaća 194 naselja u sklopu 5 gradova (Drniš, Knin, Skradin, Šibenik, Vodice) te 15 općina (Bilice, Biskupija, Civljane, Ervenik, Kijevo, Kistanje, Murter - Kornati, Pirovac, Primošten, Promina, Rogoznica, Ružić, Tisno, Tribunj, Unešić). Površinom Županija zauzima oko 2994 km², odnosno $5.3 \%$ hrvatskoga kopnenog teritorija (slika 1.).

Prijelaz sa sustava prostorno velikih općina na sustav sitnih općina odgovara prilagodbi europskom modelu s jačanjem lokalne samouprave. Ovaj proces trebao bi djelovati u smjeru jačega aktiviranja lokalnih resursa te sveobuhvatnijega i difuznijega razvoja u prostoru (Magaš, 2000.). Pritom upitna ostaje mjera pretjeranoga usitnjavanja lokalnih jedinica. Slično je i u suprotnim slučajevima kada se u težnji održavanja "stare" općine onemogućavalo nekim manjim središtima da afirmiraju svoje općine (Magaš, 2000.).

Slika 1.

Upravno-teritorijalni ustroj Šibensko-kninske županije

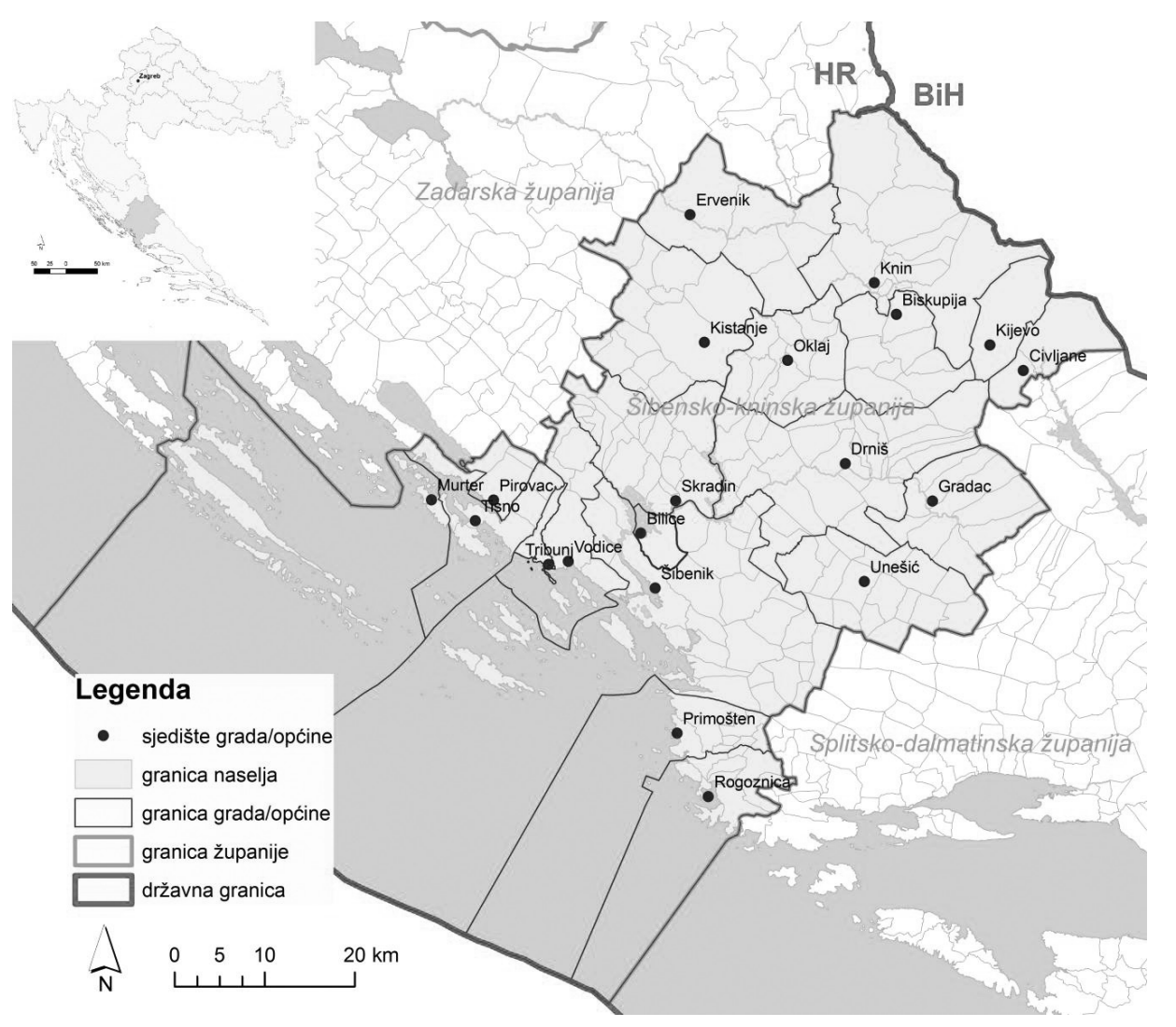


U Šibensko-kninskoj županiji svi demografski trendovi dodatno su pogoršani u vrijeme Domovinskoga rata, pri čemu se ukupan broj stanovnika ovoga područja 1991. - 2001. smanjio za gotovo 40 000, tj. na oko 113000 stanovnika (DZS, 2001.). U međupopisnom razdoblju 2001. - 2011. broj stanovnika smanjen je za dodatne 3 500, odnosno 3.2\%, što je najveća negativna stopa među županijama Južnoga hrvatskog primorja $^{4}$ (DZS, 2011.).

Industrijalizacija gradskih središta i razvoj turizma u priobalju te procesi deagrarizacije i deruralizacije koji su ponajviše zahvatili manja naselja u zagorskom prostoru i otoke, ostavili su za sobom sliku regionalnih dispariteta koji i danas obilježavaju prostor Šibensko-kninske županije. Domovinski rat dodatno je poremetio razvojne procese, a čak i Šibenik kao najsnažnije središte rada na području Županije teško se snašao u tranzicijskom razdoblju i suočio s potrebom restrukturiranja klasičnih industrijskih grana ${ }^{5}$, uz jaču orijentaciju na uslužne djelatnosti.

\section{Zakonodavni okvir prostornog planiranja u Hrvatskoj od druge polovice 20. stoljeća}

Kroz posljednjih pola stoljeća u Hrvatskoj je donesen niz zakona i pravilnika koji prate i reguliraju prostorno uređenje. Glavni dokumenti prostornoga uređenja propisivani su kroz pet osnovnih zakonskih akata (tablica 1.).

Prvi poslijeratni Zakon o urbanističkom i regionalnom prostornom planiranju donesen je 1961., a njime se propisuje izrada urbanističkoga i regionalnoga prostornog plana. Urbanističkim planom usmjerava se prostorni razvoj naselja; za pojedine dijelove naselja urbanistički plan može se razraditi urbanističkim projektima. Za manja naselja može se donijeti odgovarajuća odluka koja zamjenjuje urbanistički plan. Regionalni prostorni plan pak donosi se za šira područja ako razvoj većega broja naselja zahtijeva prostorno usklađivanje općih uvjeta razvoja.

${ }^{4}$ Unutar Šibensko-kninske županije najveći relativni gubitak stanovništva bilježi drniška subregija. S druge strane, popisni rezultati pokazuju pozitivna kretanja u Gradu Vodicama i općinama Bilice, Pirovac i Tribunj šibenske subregije, te većini kninske subregije. Gustoća naseljenosti Županije 2011. iznosi 36.5 st $/ \mathrm{km} 2$ što je znatno ispod hrvatskoga prosjeka od 75.8 st $/ \mathrm{km} 2$. Ispodprosječna je i gustoća naseljenosti sve tri subregije, uz očitu unutarregionalnu diferencijaciju: za drnišku subregiju (površine $842.41 \mathrm{~km} 2$ ) ona iznosi $14.1 \mathrm{st} / \mathrm{km} 2$; kninsku subregiju (1 105, $41 \mathrm{~km} 2)$ 20.3, a šibensku (1 045, $90 \mathrm{~km} 2) 71.7$ st/km2 (podaci za površine preuzeti iz PPŠKŽ, Knjiga 1, 2002.:6). Pri iskazivanju ukupnoga broja stanovnika te gustoće naseljenosti 2011. korišteni su prvi objavljeni rezultati Popisa stanovništva, kućanstava i stanova 2011. (DZS, Statistička izvješća 1441, $\underline{\text { www.dzs.hr) }}$ ) te su moguće korekcije objavom konačnih rezultata.

5 Paleoindustrijska paradigma bila je prevladavajuća razvojna strategija Šibenika nakon Drugoga svjetskog rata. To je vidljivo po prioritetima u izgradnji: tvorničkim kompleksima, nužnoj infrastrukturi (voda, struja, ceste), kao i izgradnji jeftinih stanova za radnike. Težište industrijskoga razvoja u Šibeniku stavljeno je na metalurgiju, dok su druge industrijske grane bile marginalno zastupljene (Poljičak, 1995.). 
Tablica 1.

Glavni dokumenti prostornoga uređenja propisani zakonskim aktima od 1961.

\begin{tabular}{|c|c|}
\hline ZAKON (br. Narodnih novina) & PROPISANI DOKUMENTI PROSTORNOG UREĐENJA \\
\hline \multirow{2}{*}{$\begin{array}{l}\text { Zakon o urbanističkom } i \\
\text { regionalnom prostornom } \\
\text { planiranju }(21 / 61,41 / 61 \\
46 / 64,29 / 66,39 / 66,18 / 69)\end{array}$} & regionalni prostorni plan \\
\hline & $\begin{array}{l}\text { urbanistički plan (program, generalni plan, detaljni plan) i } \\
\text { urbanistički projekt }\end{array}$ \\
\hline \multirow{2}{*}{$\begin{array}{l}\text { Zakon o prostornom uređenju } i \\
\text { korištenju građevinskog zemljišta } \\
(14 / 73)\end{array}$} & $\begin{array}{l}\text { razvojni planovi (republički, regionalni i općinski prostorni } \\
\text { plan, urbanistički plan* i prostorni plan područja posebne } \\
\text { namjene) }\end{array}$ \\
\hline & $\begin{array}{l}\text { provedbeni planovi (provedbeni/detaljni urbanistički plan, } \\
\text { urbanistički projekt i plan uređenja manjeg naselja) }\end{array}$ \\
\hline \multirow{3}{*}{$\begin{array}{l}\text { Zakon o prostornom planiranju } \\
\text { i uređivanju prostora }(54 / 80 \text {, } \\
16 / 86,18 / 89,34 / 91,61 / 91 \\
49 / 92,14 / 94)\end{array}$} & $\begin{array}{l}\text { prostorni plan društveno-političke zajednice (općine, gradske } \\
\text { zajednice općina); generalni urbanistički plan; prostorni plan } \\
\text { područja posebne namjene }\end{array}$ \\
\hline & $\begin{array}{l}\text { provedbeni planovi (provedbeni urbanistički plan i plan } \\
\text { uređenja manjeg naselja) }\end{array}$ \\
\hline & $\begin{array}{l}\text { mogućnost donošenja: regionalni prostorni plan, plan } \\
\text { infrastrukturnog pojasa, urbanistički projekt }\end{array}$ \\
\hline \multirow[b]{2}{*}{$\begin{array}{l}\text { Zakon o prostornom uređenju } \\
(30 / 94,68 / 98,35 / 99,61 / 00, \\
32 / 02,100 / 04)\end{array}$} & Strategija i Program prostornog uređenja Države \\
\hline & $\begin{array}{l}\text { prostorni planovi: PP županije i Grada Zagreba, PP područja } \\
\text { posebnih obilježja, PP uređenja općine i grada, generalni } \\
\text { urbanistički plan, urbanistički plan uređenja, detaljni plan } \\
\text { uređenja** }\end{array}$ \\
\hline \multirow{3}{*}{$\begin{array}{l}\text { Zakon o prostornom uređenju } i \\
\text { gradnji }(76 / 07,38 / 09,55 / 11, \\
90 / 11)\end{array}$} & $\begin{array}{l}\text { državna razina: Strategija prostornog razvoja i Program } \\
\text { prostornog uređenja Republike Hrvatske te prostorni planovi } \\
\text { područja posebnih obilježja }\end{array}$ \\
\hline & $\begin{array}{l}\text { područna (regionalna) razina: prostorni plan županije/Grada } \\
\text { Zagreba te PPPPO }\end{array}$ \\
\hline & $\begin{array}{l}\text { lokalna razina: prostorni plan uređenja velikoga grada, grada, } \\
\text { odnosno općine, urbanistički plan uređenja i detaljni plan } \\
\text { uređenja }\end{array}$ \\
\hline
\end{tabular}

Izvor: Narodne novine br. 21 iz 1961., 39 iz 1966., 14 iz 1973., 54 iz 1980., 16 iz 1986., 68 iz 1998., 76 iz 2007.

* Za gradove koji imaju funkcije značajne za širu regiju, urbanistički plan u pravilu se donosi u dvije faze - kao koncepcija prostornoga razvoja i generalni urbanistički plan.

** Dokumenti su navedeni prema izmjenama i dopunama Zakona o prostornom uređenju (NN 68/98). Njima je modificiran sustav planova iz 1994. tako da prvotni generalni plan uređenja zamjenjuje generalni urbanistički plan, a kao viša razina od DPU-a uvodi se urbanistički plan uređenja. Generalni plan uređenja donosio se za Grad Zagreb, županijska središta i ostala naselja s više od 10000 stanovnika. Izmjenama i dopunama Zakona (NN 68/98) granica od 10000 mijenja se na 15000 stanovnika za generalni urbanistički plan. 
Sljedeći, Zakon o prostornom uređenju i korištenju građevinskog zemljišta donesen je 1973., s elaboriranijim sustavom planova prostornoga uređenja te detaljnim propisima o načinu uređenja građevinskoga zemljišta. Planovi prostornoga uređenja su razvojni (dugoročni) i provedbeni, a Zakonom se detaljno propisuje sadržaj svih vrsta planova.

Zakon o prostornom planiranju i uređivanju prostora proglašen je 1980. u nešto sažetijem obliku (Zakon o građevinskom zemljištu donesen je istovremeno, ali zasebno). Zakon je propisao donošenje prostornih planova općina i gradskih zajednica općina, generalnoga urbanističkog plana za naselja gradskoga karaktera i općinska središta, prostornoga plana područja posebne namjene, provedbenih planova, te mogućnost izrade drugih planova.

Novi Zakon o prostornom uređenju usvojen je 1994., a propisani dokumenti prostornoga uređenja odraz su novoga upravno-teritorijalnog ustroja Republike Hrvatske. Od 2007. godine na snazi je posljednji u nizu, vrlo opsežan, Zakon o prostornom uređenju $i$ gradnji, koji propisuje tri razine izrade i donošenja dokumenata prostornoga uređenja: državnu, područnu (regionalnu) i lokalnu razinu. S obzirom na namjenu dokumenata prostornoga uređenja oni su strateški i provedbeni - strateški su tako svi dokumenti izuzev UPU-a i DPU-a.

Može se zaključiti da sustav prostornoga uređenja u Hrvatskoj od druge polovice 20. stoljeća karakteriziraju česte mijene zakonske osnove. Ona je pojačavana novim odredbama, koje su pobliže propisivale sadržaj, izradu i donošenje dokumenata prostornoga uređenja, pri čemu se kao posljedica promjena javljao i problem neažuriranosti planova, tj. neusklađenosti ranije izrađenih planova s tekućim zakonom. Nadalje, zakoni su propisivali obvezu usklađivanja planova užih s planovima širih područja. Navođeni su strateški i provedbeni ciljevi prostornoga uređenja, kao i tijela nadzora. Uz prostorno uređenje vežu se i odredbe o gradnji i građevinskom zemljištu, odvojeno kao samostalni zakonski akti ili kao dio samoga zakona o prostornom uređenju.

\section{Razvojna razdoblja prostornog planiranja za područje šibensko-kninske županije}

\subsection{Razdoblje 1945.- 1975. \\ Republička i (makro)regionalna razina}

Od završetka rata do sredine 1970-ih trajalo je prvo razvojno razdoblje prostornoga uređenja na području Šibensko-kninske županije, u skladu s trendovima u prostornom uređenju na republičkoj razini. Moderno poslijeratno prostorno planiranje u Hrvatskoj u početku se oslanjalo prvenstveno na područja uz jadransku obalu koja su se suočavala s izazovima iskorištavanja i zaštite prostora pod utjecajem sve snažnije turističke gradnje i razvoja naselja. 
Regionalno prostorno planiranje započelo je tako 60-ih godina ${ }^{6}$ 20. stoljeća. Urbanistički institut SR Hrvatske s nizom suradnika izradio je Program dugoročnoga razvoja i plan prostornog uređenja Jadranskog područja 1964. - 1967., u kojemu su analize i projekcije po prvi puta uzimale u obzir čitavu primorsku Hrvatsku, ali i manje cjeline unutar nje: Istru, Hrvatsko primorje, Sjevernu Dalmaciju, Srednju Dalmaciju i Južnu Dalmaciju.

Nadalje, suradnja Vlade SFRJ s Ujedinjenim narodima te suradnja među republikama unutar SFRJ rezultirala je izradom Regionalnog prostornog plana Južnog Jadrana u okviru Projekta Južni Jadran 1968. te Koordinacionog regionalnog prostornog plana Gornjeg Jadrana u okviru Projekta Gornji Jadran 1972. godine; Regionalni prostorni plan Splitske regije dovršen je 1969. Planiranje razvoja jadranskog područja imalo je za cilj stvaranje nove razvojne okosnice u Jugoslaviji, koja bi zajedno s postojećom okosnicom u savsko-dravsko-dunavskom međurječju djelovala na ukupni razvoj tadašnje države (Koordinacioni regionalni prostorni plan Gornjeg Jadrana: završni izvještaj [KRPPGJ], 1972.).

U sklopu Projekta Gornji Jadran izrađen je KRPPGJ te 16 detaljnih urbanističkih planova za područja pretežno pogodna za turistički razvoj u tadašnjim općinama. KRPPGJ izradili su Urbanistički institut SR Hrvatske i Urbanistični inštitut SR Slovenije sa suradničkim organizacijama, a obuhvatio je prostor od slovenskih visokih Alpa do sjeverne Dalmacije. U najjužnijem dijelu planom su obuhvaćene tadašnje općine Šibenik, Drniš i Knin. Postavljen je okvirni društveno-gospodarski program razvoja i izrađen prostorni plan - model razvoja regije do 2000. Sjeverna Dalmacija, posebno prostor od Zadra do Šibenika, zasnivajući razvoj na industriji, poljoprivredi i turizmu, u budućnosti je trebala preuzeti značajnu ulogu u razvoju nerazvijenih područja u zaobalju (Dalmatinska zagora, Bukovica, Lika). Uz Split kao središte južnohrvatske makroregije, Zadar i Šibenik predviđeni su kao centri (sub)regija, Knin kao centar mezoregije te Biograd, Benkovac, Obrovac, Pag i Drniš kao centri mikroregija (KRPPGJ, 1972.). Prema Mattioni (2003.) ideja povezivanja Šibenika i Zadra počivala je uglavnom na koncentraciji industrijskih kapaciteta za koje je trebala što duža obalna fronta. Zadarsko i šibensko područje trebalo je biti i jedno od područja turističkoga razvoja, primarno namijenjeno domaćim turistima (osobito kopneni dio), te turistima srednje i niže kupovne moći. ${ }^{7}$

U projektima Južni i Gornji Jadran opći napredak jadranske regije viđen je u kombinaciji prije svega industrije i turizma (da bi se izbjegla monoprivredna struktura). Strategija rasta bila je gotovo doktrinirano stajalište te se za svaki od gradova plani-

${ }^{6}$ Regionalni prostorni plan kotara Krapina (1958.) bio je prvi regionalni prostorni plan u Hrvatskoj. Između 1961. i 1964. izrađen je Regionalni prostorni plan kotara Split koji je obuhvatio tadašnjih sedam srednjodalmatinskih općina (Šimunović, 1982.). U razdoblju 1967.- 1969. izrađen je i Regionalni prostorni plan Istre.

${ }^{7}$ Primjer detaljnih planova izrađenih u sklopu Projekta Gornji Jadran je i Detaljni plan ŠibenikSrima iz 1971. godine. U okviru radova na planu, a u nedostatku Generalnoga plana Šibenika, napravljena je i Studija razvoja Šibenika te očekivanoga utjecaja grada na područje poluotoka Srima (Detaljni plan Šibenik-Srima, Projekt Gornji Jadran, 1971.). 
rao rast broja stanovnika i teritorija. U pogledu ostvarenja regionalni planovi računali su na izradu planova niže razine, a investicije za provedbu trebale su biti osigurane većinom u ekonomijama samih regija što se pokazalo nerealnim, tako da detaljni planovi uglavnom nisu provedeni. Od golemoga mehanizma planiranja najviše koristi imale su stručne institucije koje su zahvaljujući novom iskustvu razvile metodologiju integralnoga (gospodarskoga i prostornoga) planiranja (Mattioni, 2003.).

Suradnja s UN-om nastavila se i 1978. dovršen je Projekt Jadran 3 - Projekt o zaštiti okoliša u jadranskoj regiji Jugoslavije, koji je utjecao na stručne institucije na način da je zaštita okoliša nakon 70-ih godina postala neupitan sadržaj prostornih i urbanističkih planova (Mattioni, 2003.).

U ovome razdoblju općina Knin uključena je u međuopćinski plan: Koncepcija i program razvoja Bukovice; Regionalni prostorni plan općina Benkovac-Knin-Obrovac, izrađen 1975. Razvojna orijentacija u planu podrazumijevala je koncentraciju rada i opremu društvenoga standarda uz formiranje gravitacijskih područja. Centri su klasificirani kao centar mezoregije (Knin), mikroregije (Benkovac, Obrovac) te lokalni centar (Jesenice, Kruševo, Smilčić, Polača, Stankovci, Lišane Ostrovičke, Kistanje, Kaštel Žegarski, Ervenik, Strmica, Kosovo, Kijevo) (Koordinacioni prostorni plan Dalmacije [KPPD], knjiga 3, 1977.).

Prvi Prostorni plan SR Hrvatske: godina 2000. nastavlja se na regionalne planove, a dovršen je 1974. Na njegovoj pripremi bile su angažirane brojne stručne i znanstvene ustanove. Popraćen je i Planerskim atlasom SR Hrvatske, koji se sastojao od niza analitičkih i statističkih karata postojećega stanja te pojedinih trendova. Predviđene su tri glavne okosnice razvoja: posavsko-podunavska, okosnica na pravcu Budimpešta - Sjeverni Jadran te obalna okosnica, kojoj bi poticaj dalo uklanjanje svojevrsnoga diskontinuiteta prisutnoga na prostoru Like (Prostorni plan SR Hrvatske godina 2000.: završni izvještaj [PPSRH], 1974.). Treba naglasiti da je ovaj Plan imao razrađenu organizaciju i metodologiju izrade planske dokumentacije, a u razvojnim koncepcijama, barem deklarativno, velika pozornost bila je usmjerena k zaštiti okoliša. Za pojedine projekcije u Planu izražene su tri moguće varijante urbanoga sustava: koncentracije stanovništva i središnjih funkcija u zagrebačkoj, osječkoj, riječkoj i splitskoj regiji, disperznoga sustava središnjih naselja i stanovništva, te međuvarijanta koja se preporuča kao optimalna. Uz centre republike, makroregije i subregije, planirane su kategorije centara mezoregije, mikroregije (općinska središta) te zone (lokalna središta). Na području Južne Hrvatske uz Split, kao makroregionalni centar, trebaju se jače razvijati subregionalni centri Zadar, Dubrovnik, Ploče-Metković i Šibenik. Splitska regija sa Šibenikom i Zadrom predviđena je kao najznačajnije razvojno žarište dalmatinskoga obalnog pojasa pa i zapadnobosanskoga i hercegovačkoga zaobalja. Na prometnom čvorištu Južne Hrvatske prema unutrašnjosti predviđen je razvoj Knina kao mezoregionalnoga centra koji može preuzeti i pomoćne funkcije za veće centre na obali. Za dalmatinsku makroregiju općenito, a tako i za područje današnje Šibensko-kninske županije predviđen je daljnji industrijski razvoj, uz nove kapacitete crne i raznobojne metalurgije, ali i razvoj tercijarnih djelatnosti - turizma, prometa te pratećih djelatnosti (PPSRH, 1974.).

Krajem ovoga razdoblja izrađen je i jedan prostorni plan posebne namjene - Plan područja rijeke Krke, Čikole i Krčića. Prema planu PPPPN Krka centri su klasificirani 
na sljedeći način: regionalni centar - Šibenik; regionalni podcentar - Drniš, Knin; historijski grad - Skradin; općinski podcentar - Kistanje, Oklaj; ruralna naselja u zaobalju - Prokljan, Nos Kalik, Rupe, Deranj, Škarica, Puljane (KPPD, knjiga 3, 1977.).

\section{Lokalna razina}

Na užem području današnje Šibensko-kninske županije počecima poslijeratnoga planiranja uređenja prostora može se smatrati izrada pojedinih regulacijskih planova i osnova. Potkraj Drugoga svjetskog rata Tehnički odjel ZAVNOH-a je od Royal Air Forcea zatražio zračni snimak područja Bilica u svrhu izrade Regulacijskoga plana Bilica. Na osnovi zračne snimke regulacijski plan (od kojega je jedan dio i izveden) izradili su Josip Seissel, Dragan Boltar i Mirko Miličić (Kranjčević, 2002.). Dragan Boltar autor je i prvoga poslijeratnog urbanističkog plana Šibenika - tada zvanoga direktivnim regulacijskim planom, iz 1947., koji je kasnije prerastao u generalni urbanistički plan dovršen 1954. Boltarov plan slovi kao pionirski iskorak u suvremenom urbanističkom planiranju (Šprljan, 1997.).

U prvome razdoblju za područje Drniša i Knina također su postojale regulacijske osnove: Knina iz 1947. - 1948. (Općina Knin, Osnova korištenja i zaštite prostora [OKIZP], 1993.) te užega centra Drniša iz 1955. (KPPD, knjiga 2, 1976.) (tablica 2./355 str.).

Za grad Knin Nacrt Generalnog urbanističkog plana usvojen je već 1956., uz kasnije izmjene. Odluka koja zamjenjuje urbanistički plan za područje grada Knina donesena je 1968. Izgradnja grada Drniša usmjeravana je na temelju Odluke koja zamjenjuje urbanistički plan za grad Drniš $i$ njegovo uže područje. Za područje općine Šibenik donesene su Odluke koje zamjenjuju regionalne prostorne planove obalnoga pojasa općine Šibenik u dva navrata, 1967. i 1971. Odluke koje zamjenjuju urbanističke planove donesene su za Tribunj i Primošten, a Generalni plan područja Primošten - Rogoznica, izrađen 1971., konačno je donesen 1973. Urbanistički plan usvojen je i za otok Prvić.

Provedbu planova osiguravale su općinske službe izradom urbanističkih uvjeta izgradnje na temelju provedbenih planova te izdavanjem građevinskih dozvola. Ulogu u provedbi imale su i inspekcijske službe. U Dalmaciji je izrada razvojnih i provedbenih planova koncentrirana uglavnom u gradskim naseljima jer je Zakon iz 1973. obvezao izradu urbanističkih planova za gradove ili veća naselja, a provedbenih za područja intenzivne izgradnje, naročito u obalnom pojasu (KPPD, knjiga 2, 1976.). Provedbeni planovi bili su tako u većem broju izrađeni za područje općine Šibenik (gradsko područje i turističke zone), dok su općine Knin i, posebno, Drniš zaostajale. Veliki dijelovi dalmatinskih općina (izuzev središnjih naselja u većini zagorskih općina) ostajali su nepokriveni planovima pa se izgradnja, često dosta intenzivna u blizini općinskih središta i neposrednom zaobalju regionalnih središta, odvijala bez planova. Smjernice za širenje naselja u okviru općinskih planova bile su jedini planski dokumenti seoskih naselja. Osim toga, nerazvijene općine, poput tadašnje općine Drniš, susretale su se i s materijalnim i kadrovskim poteškoćama u organizaciji urbanističkih službi (KPPD, knjiga 2, 1976.). 
Tablica 2.

Prostorni planovi za područje današnje Šibensko-kninske županije izrađeni 1945. - 1975., po razinama

\begin{tabular}{|c|c|c|c|}
\hline \multicolumn{4}{|c|}{ VRSTA I NAZIV PLANA /DONOŠENJE PLANA/ } \\
\hline \multicolumn{4}{|c|}{ REPUBLIČKA I (MAKRO) REGIONALNA RAZINA } \\
\hline \multicolumn{4}{|c|}{ PP SR Hrvatske: godina 2000. (+ Planerski atlas) /1974./; } \\
\hline \multicolumn{4}{|c|}{$\begin{array}{l}\text { Program dugoročnoga razvoja i plan prostornoga uređenja Jadranskoga područja SRH, 1964.-1967. } \\
\text { (Veliki Jadran); Koordinacioni RPP Gornjeg Jadrana, 1972.; Koncepcija i program razvoja Bukovice, } \\
\text { RPP općina Benkovac-Knin-Obrovac, 1975.; }\end{array}$} \\
\hline \multicolumn{4}{|c|}{ PPPPN - Plan Krke, Čikole i Krčića /1975.?/. } \\
\hline \multicolumn{4}{|l|}{ LOKALNA RAZINA } \\
\hline \multicolumn{4}{|l|}{ OPĆINA DRNIŠ } \\
\hline \multicolumn{2}{|c|}{$\begin{array}{l}\text { Program - idejna regulaciona osnova užega } \\
\text { centra Drniša /1955./; }\end{array}$} & \multicolumn{2}{|c|}{$\begin{array}{l}\text { OKZ UP za grad Drniš i njegovo uže područje /SV } \\
21 / 67 / \text {. }\end{array}$} \\
\hline \multicolumn{4}{|c|}{ OPĆINA KNIN } \\
\hline \multicolumn{2}{|c|}{$\begin{array}{l}\text { Knin - detaljna regulaciona osnova, 1947.- } \\
1948 \text {; }\end{array}$} & \multicolumn{2}{|c|}{ OKZ UP za područje grada Knina /SV 17/68/; } \\
\hline \multicolumn{2}{|c|}{$\begin{array}{l}\text { Nacrt GUP-a za grad Knin /24.05.1956./, izmj. i } \\
\text { dop. Odluke o GUP-u /28.02.1958., 20.10.1958., } \\
\text { 07.09.1959./; }\end{array}$} & \multicolumn{2}{|c|}{ Urbanistički program grada Knina /1973./. } \\
\hline \multicolumn{4}{|c|}{ OPĆINA ŠIBENIK } \\
\hline \multicolumn{4}{|c|}{$\begin{array}{l}\text { OKZ RPP obalnoga pojasa općine Šibenik /SV 08/67, 19/67, 16/68/; OKZ RPP obalnoga pojasa općine } \\
\text { Šibenik /SV 01/71, 03/71, 12/71/; }\end{array}$} \\
\hline \multicolumn{2}{|c|}{ Direktivni regulacijski plan Šibenika, 1947.; } & \multicolumn{2}{|c|}{ OKZ UP Primoštena /SV 12/70/; } \\
\hline \multicolumn{2}{|c|}{ GUP Šibenika /1954./; } & \multicolumn{2}{|c|}{$\begin{array}{l}\text { GP područja Primošten - Rogoznica /SV 08/71 } \\
\text { (privremeno), 1973./ }\end{array}$} \\
\hline \multicolumn{2}{|l|}{ OKZ UP Primoštena /SV 04/66/; } & \multicolumn{2}{|c|}{ UP otoka Prvića /SV $10 / 71 /$} \\
\hline \multicolumn{4}{|l|}{ OKZ UP Tribunja /SV 16/67/; } \\
\hline Regulacijski plan Bilica, 1945; & \multicolumn{2}{|c|}{ PUP tur. zone Solaris, 1971.; } & $\begin{array}{l}\text { PUP Draga - Plišac, 1974./ } \\
\text { donesen?/; }\end{array}$ \\
\hline $\begin{array}{l}\text { Predio Draga, 1954. (provedbeni) } \\
\text { /1954./; }\end{array}$ & \multicolumn{2}{|c|}{ PUP st. zona pod Solarisom /1972./; } & $\begin{array}{l}\text { PUP uvala Jazine u Tijesnom } \\
\text { 1975./\% }\end{array}$ \\
\hline DUP st. naselje Vidici /1968.?/; & \multicolumn{2}{|c|}{ PUP Jurasi /SV 01/73/; } & $\begin{array}{l}\text { PUP mjesto Zlarin, } 1975 . / \\
\text { donesen?/; }\end{array}$ \\
\hline $\begin{array}{l}\text { OKZ regionalni (urbanist.) plan ind. } \\
\text { bazena Ražine (otpadne vode) /SV } \\
04 / 70 / ;\end{array}$ & \multicolumn{2}{|c|}{$\begin{array}{l}\text { PUP mikrorajona Šubićevac /SV } \\
01 / 73 / ;\end{array}$} & PUP Šubićevac /SV 08/75/; \\
\hline $\begin{array}{l}\text { OKZ regulacioni plan (lokacija i } \\
\text { uređenje gradskog groblja) } / \text { SV } 10 / 70 \text {, }\end{array}$ & \multicolumn{2}{|c|}{ DUP Šibenik - Srima /SV 01/73/; } & $\begin{array}{l}\text { PUP st. naselje Meterize, } 1975 . \\
\text { /donesen?/; }\end{array}$ \\
\hline DP Primoštena /SV 08/71/; & \multicolumn{2}{|c|}{$\begin{array}{l}\text { PUP uvale Rastovac - Tijesno /SV } \\
15 / 74 / ;\end{array}$} & $\begin{array}{l}\text { PUP st. naselje Ražine, } 1975 . / \\
\text { donesen?. }\end{array}$ \\
\hline
\end{tabular}

Napomena 1: Kod vrste i naziva planova korištene su skraćenice: PPPPN - prostorni plan područja posebne namjene, RPP - regionalni prostorni plan, GUP - generalni urbanistički plan, UP - urbanistički plan, GP - generalni plan, DP - detaljni plan, PUP - provedbeni urbanistički plan, DUP - detaljni urbanistički plan; OKZ - odluka koja zamjenjuje. Puni nazivi navođeni su ako skraćenica ne bi bila dovoljno jasna. Napomena 2: Nazivi planova odgovaraju nazivima u izvorima, a samo u pojedinim slučajevima su skraćeni radi preglednosti.

Napomena 3: Unutar kosih crta (//), kada je to bilo moguće, navedeni su brojevi Službenoga vjesnika općine Drniš, Knin i Šibenik s odlukama o donošenju pojedinih planova. Ako nije bilo moguće sigurno utvrditi je li ili kada je službeno donesen određeni plan, nakon naziva navedena je godina izrade.

Izvor: prikupljena prostorno-planska dokumentacija; SV općine Drniš, Knin i Šibenik 1963. - 1973.; KPPD, knjiga 2, 1976.; Općina Knin, OKIZP, 1993. 


\subsection{Razdoblje 1975.- 1992.}

\section{Republička i (makro)regionalna razina}

Sredinom 1970-ih počele su pripreme na izradi Koordinacionog prostornog plana Dalmacije. U pripremnoj fazi Urbanistički zavod Dalmacije izradio je studije ${ }^{8}$ metodologiji i organizaciji izrade KPPD te stanju urbanističkih službi i urbanističkoplanske dokumentacije na području Dalmacije. Budući da su dokumentaciju izradivale različite institucije (3/4 Urbanistički institut SRH i UZ Dalmacije, a 1/4 druge planerske institucije), karakterizirala ju je neujednačenost s obzirom na metodološki pristup, sadržaj, razinu usklađenosti sa Zakonom iz 1973., pa i razvojne koncepcije, te je bilo potrebno uskladiti je za izradu KPPD. Ustanovljeno je da se mali dio postojećih razvojnih planova u potpunosti provodi. Zaključeno je i da se dotadašnje planiranje na prostoru Dalmacije više svodilo na izradu statičnih dokumenata - projekcija nego na dinamično usmjeravanje budućega razvoja (KPPD, knjiga 3, 1977.).

Prostorni plan Zajednice općina Split, koji je izradio UZ Dalmacije sa suradnicima, usvojen je 1982. Sa startnom 1975., a ciljnom 2000. godinom, bio je to koordinacijski razvojni plan s ciljem usklađenja općinskih, subregionalnih i ostalih prostornih planova na području Dalmacije i planskih koncepcija od zajedničkoga interesa. Obuhvaćene su 22 općine na području Dalmacije, među njima i općine Drniš, Knin i Šibenik. Cijeli prostor obilježavale su vrlo intenzivne društveno-ekonomske i demografske promjene, izraženi procesi industrijalizacije i urbanizacije s koncentracijom stanovništva u priobalnom pojasu, a istovremeno deagrarizacija i iseljavanje stanovništva iz unutrašnjosti i s otoka. Procesi transformacije naselja izazvali su probleme u prostoru i upozorili na potrebu planskoga usmjeravanja urbanizacije (Šimunović, 1982.).

Planom je predviđena veća disperzija stanovništva i razvitak manjih središnjih naselja, uz usporavanje rasta broja stanovnika u obalnim središtima. Tako se među posebnim ciljevima dugoročnoga razvoja naglašava ostvarivanje policentričnoga sustava industrijsko-urbane strukture, pri čemu je u prostorno-strukturnom modelu Dalmacija podijeljena na pet regionalnih cjelina - težišta razvoja: zadarsko, šibensko, splitsko, neretvansko i dubrovačko područje. Ističe se važnost povezivanja razvojnih žarišta i bolje valorizacije geoprometnoga položaja ZO Split - u povezivanju s neposrednim i daljim zaleđem te jačanjem primorske okosnice razvoja države. U sustavu središnjih naselja Split je definiran kao makroregionalni centar; Zadar, Dubrovnik i Šibenik kao regionalni; Metković-Kardeljevo (današnje Ploče) kao subregionalni, te Knin kao mezoregionalni centar. Mikroregionalnu razinu imali su općinski

8 Skupština Zajednice općina Split 1975. je usvojila Program rada u oblasti planiranja prostornog uređenja na području Dalmacije. U prvoj fazi Programa rada izrađene su tri studije: Metoda i organizacija izrade, Snimak stanja urbanističkih službi i urbanističke dokumentacije na području Zajednice općina Split, te Vrednovanje i ocjena urbanističko-planske dokumentacije na području Dalmacije (KPPD, knjiga 3, 1977.). 
centri, a najnižu razinu centri razvojnoga područja. Razrada i primjena ovoga Plana predviđena je prvenstveno kroz općinske prostorne planove (Šimunović, 1982.).

Drugi Prostorni plan SR Hrvatske usvojen je 1989., kratko prije osamostaljenja Republike Hrvatske. Dane su planske smjernice do 2000., s daljnjom razradom do 2015. Navodi se da je na konflikte u određenim područjima utjecala nepovezanost društveno-ekonomskoga i prostornoga planiranja, nepoštivanje postojećih prostornih planova i drugih zakonskih propisa, ali nerijetko i pristup korištenju prostora u planovima. Među ostalim, urbano bazirana industrijalizacija utjecala je na neravnomjeran razvoj te brojne funkcionalne i ekološke konflikte u prostoru. Zaštita okoline bila je deklarativna, a u stvarnosti se često podlijegalo lokalnim i parcijalnim interesima.

Kao zadatak razvoja u prostoru navedeno je optimalno i racionalno korištenje prostora, uz jačanje policentričnoga sustava'. Planiranim okosnicama razvoja Hrvatske ostale su posavsko-podunavska, jadranska, okosnica Budimpešta - sjeverni Jadran te okosnica kroz Liku. Kao jedno od razvojnih težišta predviđeno je područje Splita, Šibenika, Zadra i Knina, čiji se razvitak treba temeljiti na industriji, turizmu i (manjim dijelom) poljoprivredi, uz značajnu ulogu u strategiji razvoja područja u zaobalju (Dalmatinska zagora, Lika, zapadna Bosna i Hercegovina) ${ }^{10}$. Uz Zagreb kao republički centar, predviđeni su još Osijek, Rijeka i Split kao središta makroregija - s pratećim satelitskim naseljima. U sustavu središnjih naselja Šibenik je središte regije i jedan od glavnih polova razvoja unutar policentričnoga sustava, Knin je manje regionalno središte, a Drniš se ubraja među ostala središta općina.

U razdoblju 1975. - 1992. za prostor današnje Šibensko-kninske županije izrađena su i tri prostorna plana područja posebne namjene. Za Kornate je ovakav plan izrađen već 1978., međutim, proceduralno nije bio dovršen. NP "Kornati" službeno je proglašen 1980., a NP "Krka" 1985. godine. Za oba nacionalna parka Sabor SR Hrvatske usvojio je prostorne planove 1990.

\section{Lokalna razina}

U drugom razdoblju nastavljena je izrada razvojne i provedbene prostorno-planske dokumentacije za područje općina Drniš, Knin i Šibenik (tablica 3.). Za sve tri

${ }^{9}$ U odnosu na dotadašnje stanje u prostoru predviđeno je više kategorija (stupnjeva) središnjih naselja te povezani razvoj određenih središta unutar metropolitskih područja, gradskih regija, gradskih aglomeracija ili konurbacija - međusobno dijeleći funkcije koje odgovaraju pojedinoj kategoriji središnjih naselja (Prostorni plan SR Hrvatske [PPSRH], NN 12/89).

10 U sjevernoj i srednjoj Dalmaciji oblikovao se svojevrstan industrijski trokut Split-ZadarŠibenik, s Kninom u unutrašnjosti. Drniš još uvijek ima obilježja tradicionalne gospodarske nerazvijenosti. S turističkoga aspekta šibenska regija nije dovoljno razvijena usprkos velikim potencijalima, a turistička ponuda je rascjepkana. Važnija središta su Murter, Vodice i Primošten; intenzivnije treba razvijati posebno otoke i sam grad Šibenik, te vrednovati nacionalne parkove "Krka" i "Kornati" (PPSRH, NN 12/89). 
izrađeni su općinski prostorni planovi, ali je samo za općinu Drniš bio stvarno i na snazi, i to već od 1978. Za općine Knin i Šibenik planovi su izrađeni krajem 1980-ih godina, ali nisu stupili na snagu zbog problema s bespravnom gradnjom (Šibenik), odnosno prekida procedure usvajanja uslijed Domovinskoga rata (Knin) (Prostorni plan Šibensko-kninske županije [PPŠKŽz, Knjiga 1, 2002.).

Tablica 3.

Prostorni planovi za područje današnje Šibensko-kninske županije izrađeni 1975. - 1992., po razinama

\begin{tabular}{|c|c|c|}
\hline \multicolumn{2}{|c|}{ VRSTA I NAZIV PLANA /DONOŠENJE PLANA/ } & REPUBLICKA I (MAKRO)REGIONALNA RAZINA \\
\hline \multicolumn{3}{|c|}{ PP SR Hrvatske /NN 12/89/; } \\
\hline \multicolumn{3}{|c|}{$\begin{array}{l}\text { Projekt o zaštiti čovjekove okoline u Jadranskoj regiji Jugoslavije, 1978. - Jadran 3; PP ZO Split } \\
\text { /1982./. }\end{array}$} \\
\hline \multicolumn{3}{|c|}{ OPĆINA DRNIŚ } \\
\hline \multicolumn{3}{|c|}{ PP općine Drniš /SV 12/78, 14/84, 11/88,15/88 i 01/90/; } \\
\hline \multicolumn{3}{|c|}{ GUP grada Drniša /SV 17/86, 01/90/; } \\
\hline PUP novoga centra Drniša /SV 1983., SV 1989./; & $\begin{array}{l}\text { PUP dijela industrijske } \\
\text { zone XI (Građa Solin) / } \\
\text { SV 1989./; }\end{array}$ & $\begin{array}{l}\text { PUP dijela skladišno prodajne } \\
\text { zone IV (lokacija Mesoprometa) } \\
\text { /SV 01/90/. }\end{array}$ \\
\hline \multicolumn{3}{|l|}{ PP općine Knin, 1989. /SV ?/; } \\
\hline \multicolumn{3}{|c|}{ GUP grada Knina /usvojen 1975., SV 21/85, 07/86, 10/87/; } \\
\hline $\begin{array}{l}\text { PUP za područje ist. od zgrade bivše JŽ-9 u } \\
\text { Kninu, 1977. /donesen?/; }\end{array}$ & $\begin{array}{l}\text { PUP ist. uz bivšu cestu } \\
\text { AVNOJ-a (Pejton) u Kninu, } \\
\text { 1985. /donesen?/; }\end{array}$ & PUP centar II, 1986. /SV?/; \\
\hline $\begin{array}{l}\text { PUP naselja Drpina Glavica Knin /usvojen 1975., } \\
\text { SV 21/85/; }\end{array}$ & $\begin{array}{l}\text { PUP Municirije II /SV } \\
\text { 16/86, 09/89/; proširenje } \\
\text { PUP-a Municirije II, 1986. / } \\
\text { donesen?/; }\end{array}$ & $\begin{array}{l}\text { PUP sport.-rekreativnog centra } \\
\text { "Riva" - uređenje obale Krke u } \\
\text { Kninu /SV 07/86/; }\end{array}$ \\
\hline \multicolumn{3}{|c|}{ PP općine Šibenik, 1990. /nije donesen, Odluka o donošenju SV 07/85/; } \\
\hline GUP otoka Zlarina /SV 15/77/; & & $\begin{array}{l}\text { GUP Tribunj - Vodice - Srima / } \\
\text { SV 07/82, 22/83, 25/85, 14/89, 11/90, } \\
\text { 16/90/; }\end{array}$ \\
\hline \multicolumn{2}{|c|}{$\begin{array}{l}\text { UP područja otoka Murter - Pirovac /SV } 02 / 79,28 / 79,20 / 81 \text {, } \\
\text { 18/83, 8/89/; }\end{array}$} & GUP grada Šibenika /SV 14/88/; \\
\hline \multicolumn{2}{|c|}{ UP područja Primošten - Rogoznica /SV 09/80, 18/83/; } & $\begin{array}{l}\text { GUP naselja Skradin /SV 06/89 na } \\
\text { usvajanju, proceduralno nedovršen/; }\end{array}$ \\
\hline PUP Vidici /SV 08/78, 27/86, 11/87, 03/88/; & PUP Baldekin I /SV 18/85/; & $\begin{array}{l}\text { PUP tur. rekreac. zone T3 R2 } \\
\text { ŠB1 ŠB2 Slanica u Murteru } / \\
\text { SV } 22 / 88 / ;\end{array}$ \\
\hline PUP naselja Ražine /SV 04/79/; & $\begin{array}{l}\text { PUP marina Kremik /SV } \\
18 / 85,12 / 89 / ;\end{array}$ & $\begin{array}{l}\text { PUP st. naselja Križ u Šbeniku } \\
\text { /SV 03/89,07/91,-/92/; }\end{array}$ \\
\hline PUP tur. naselja Podvrške - Murter /SV 06/79/; & PUP Škopinac /SV 23/85/; & $\begin{array}{l}\text { PUP dijela centra naselja } \\
\text { Tijesno (C1 i J1) / SV 04/89/; }\end{array}$ \\
\hline PUP st. zone SN1 - Gomik - Tijesno /SV 08/80/; & PUP Baldekin III /SV 24/85/; & $\begin{array}{l}\text { PUP st. zona Stablinci - Račice } \\
\text { /SV 04/89/; }\end{array}$ \\
\hline Infrastruktura (PUMN) Tijesno /SV 12/81/; & $\begin{array}{l}\text { PUP ind. zone Vodice /SV } \\
10 / 86 / ;\end{array}$ & $\begin{array}{l}\text { PUP gradskog kupališta i } \\
\text { vikend naselja Jadrija / SV 06/89/; }\end{array}$ \\
\hline PUP Šubićevac - izmj. i dop. /SV 20/81, 02/83/; & $\begin{array}{l}\text { PUP T6 Plitka Vala - Betina } \\
\text { /SV 27/86/; }\end{array}$ & PUP naselja Skradin /SV 06/89/; \\
\hline
\end{tabular}




\begin{tabular}{|c|c|c|}
\hline PUP Smričnjak /SV 24/81/; & $\begin{array}{l}\text { PUP st. naselja Meterize /SV } \\
28 / 86,14 / 90,04 / 92 / ;\end{array}$ & $\begin{array}{l}\text { PUP parka "Maksim Gorki" u } \\
\text { Šibeniku /SV 09/89/; }\end{array}$ \\
\hline PUP Bristine - Betina /SV 09/82/; & $\begin{array}{l}\text { PUP tur. zone T1 i T2 - } \\
\text { Pirovac /SV 30/86, 15/88, } \\
\text { 16/90/; }\end{array}$ & $\begin{array}{l}\text { PUP tur. Zone Punta - Vodice / } \\
\text { SV 09/89/; }\end{array}$ \\
\hline PUP Dočine - Vodice /SV 15/82/; & $\begin{array}{l}\text { PUP tur. zone T2 i T3 } \\
\text { Lovišća Jezera /SV 08/87, } \\
\text { 15/87/; }\end{array}$ & PUP Križine Tribunj /SV 09/89/; \\
\hline $\begin{array}{l}\text { PUMN Grebaštica - Sparadići - izmj. i dop. / } \\
\text { SV } 24 / 82 / \text {; }\end{array}$ & PUP centar Vodice /1988??; & $\begin{array}{l}\text { PUP st. naselja Bosanski Dolac } \\
\text { /SV 09/89/; }\end{array}$ \\
\hline PUP autokamp Jasenovo /SV 14/83/; & $\begin{array}{l}\text { PUP st. zone (Vs18) } \\
\text { Mličevac /SV 03/88, 02/90/; }\end{array}$ & $\begin{array}{l}\text { PUP naselja Platić Zatoglav / } \\
\text { SV 09/89/; }\end{array}$ \\
\hline PUMN Murter - Hramina /SV 18/83/; & $\begin{array}{l}\text { PUP st. zone Blata - } \\
\text { Pudarice - Vodice /SV 03/88/; }\end{array}$ & $\begin{array}{l}\text { PUP tur. naselja Solaris /SV } \\
11 / 89 / ;\end{array}$ \\
\hline $\begin{array}{l}\text { PUP dijela naselja Primošten (Zdravstvena } \\
\text { stanica) /SV 18/83/; }\end{array}$ & $\begin{array}{l}\text { PUP st. zone Stanine (Vs14) } \\
\text { Vodice /SV 03/88/; }\end{array}$ & $\begin{array}{l}\text { DPU prostora Skradinski buk / } \\
\text { SV } 01 / 90 / \text {; }\end{array}$ \\
\hline PUP naut. centra Jezera /SV 22/83/; & $\begin{array}{l}\text { PUP obalnog pojasa Srima } \\
\text { SR } 11 \mathrm{i} \text { SC } 3 \text { /SV } 03 / 88 /\end{array}$ & $\begin{array}{l}\text { PUP kupališno-rekreac. zone } \\
\text { Vodice /SV 01/90/; }\end{array}$ \\
\hline PUP naut. centra Vodice /SV 22/83/; & $\begin{array}{l}\text { PUP centralnog dijela } \\
\text { naselja Betina (C1, C2 i B2) } \\
\text { /SV 03/88/; }\end{array}$ & $\begin{array}{l}\text { PUP servisno-komercijalne } \\
\text { zone Podsolarsko /SV 03/90/; }\end{array}$ \\
\hline PUP NC o. Žut /SV 25/83/; & $\begin{array}{l}\text { PUP srednjošk. centra u } \\
\text { Šibeniku } / \text { SV } 06 / 88 / \text {; }\end{array}$ & $\begin{array}{l}\text { PUP tur. naselja "Medine" - } \\
\text { Rogoznica } / \text { SV 05/90/; }\end{array}$ \\
\hline PUP otoka Obonjan /SV 08/84/; & $\begin{array}{l}\text { PUP pekare i distributivnog } \\
\text { centra Ražine } / \mathrm{SV} 08 / 88 / \text {; }\end{array}$ & $\begin{array}{l}\text { PUP naut. centra Tribunj /SV } \\
11 / 90 / \text {. }\end{array}$ \\
\hline PUP Brodarica /SV 19/84/; & $\begin{array}{l}\text { PUP lučko-pretovarne zone } \\
\text { Šibenik } / \mathrm{SV} 12 / 88 / ;\end{array}$ & $\begin{array}{l}\text { PUP naut. centra Kaprije /SV } \\
\text { 16/90/; }\end{array}$ \\
\hline PUP prometnica naselja Srima /SV 12/84/; & $\begin{array}{l}\text { PUP tur. zone Rastovac T5 } \\
\text { u Tijesnom / SV 13/88/; }\end{array}$ & $\begin{array}{l}\text { PUP područja Bilo-strane /SV } \\
16 / 90 / ;\end{array}$ \\
\hline $\begin{array}{l}\text { PUP pov. jezgre Šibenika (prethodni radovi i } \\
\text { program izrade, I. faza) } / \text { SV } 24 / 84,15 / 88 / \text {; }\end{array}$ & $\begin{array}{l}\text { PUP st.-rekreac. zone } \\
\text { Šubićevac /SV 14/88, 03/91/; }\end{array}$ & $\begin{array}{l}\text { PUP dijela st. zone Mažurica / } \\
\text { SV } 17 / 90,10 / 91,03 / 92 / ;\end{array}$ \\
\hline PUP starog dijela naselja Primošten /SV 06/85/; & $\begin{array}{l}\text { PUP st. zone Vs20 i dijela } \\
\text { tur. zona Vt3 i Vt4 u } \\
\text { Vodicama (V. Gortan) /sV } \\
14 / 88 / \text {; }\end{array}$ & $\begin{array}{l}\text { PUP tur. rekreac. zone Jazine - } \\
\text { Prisliga u Tisnom /SV 03/91/; }\end{array}$ \\
\hline PUP Lozica /SV 09/85/; & $\begin{array}{l}\text { PUP dijela centra Pirovca } \\
\text { C3 /SV 14/88/; }\end{array}$ & $\begin{array}{l}\text { PUP uvale Luka u Tisnom / } \\
\text { SV 03/91/. }\end{array}$ \\
\hline PUP Kopača /SV 09/85/; & $\begin{array}{l}\text { PUP tur. naselja "Marina } \\
\text { Lučica" - Primošten /SV } \\
\text { 14/88/; }\end{array}$ & \\
\hline PUP Rogoznica /SV 09/85/; & $\begin{array}{l}\text { PUP tur. zone Kosirina T7 / } \\
\text { SV 17/88/; }\end{array}$ & \\
\hline
\end{tabular}

Napomena 1: Kod vrste i naziva planova korištene su skraćenice: PPPPN - prostorni plan područja posebne namjene, GUP - generalni urbanistički plan, UP - urbanistički plan, PUP - provedbeni urbanistički plan, DPU - detaljni plan uređenja, PUMN - plan uređenja manjega naselja. Puni nazivi navođeni su ako skraćenica ne bi bila dovoljno jasna. Napomena 2 i 3: kao za tablicu 2.

Izvor: prikupljena prostorno-planska dokumentacija; Općina Knin, OKIZP,1993.; Općina Šibenik, OKIZP,1993.; PMZUS, IOS Grada Šibenika, SV Županije Šibenske 04 od 1995.; IOS i PMZUS Grada Knina, SV Šibensko-kninske županije 02 od 1998.; IOS i PMZUS Šibensko-kninske županije, SV Šibensko-kninske županije 03 od 1999.

Prognoze i planirani sadržaji u Prostornom planu općine Drniš odnosili su se na razdoblje do 2000. Planom je bio određen policentrični razvoj na prostoru općine, jačanjem lokalnih središta. Međutim, intenzitet njihova razvoja nije pratio intenzitet razvoja Drniša kao općinskoga središta. Razlozi tomu nalaze se u inertnosti dislociranja djelatnosti iz općinskoga u ostala središta, nedostatku stručne snage i slaboj infrastrukturnoj opremljenosti (komunalnoj i društvenoj) lokalnih središta (Izvješće 
o stanju u prostoru [IOS] i Program mjera za unapređenje stanja u prostoru [PMZUS] Grada Drniša, SV 01/00). Ukupan dugoročni razvoj Plan je temeljio na razvoju poljoprivredne proizvodnje, industrijskih grana komplementarnih razvoju jadranskoga područja te razvoju turizma kao dotad nerazvijene grane. Ovaj dokument je, osim na području općinskoga središta Drniša, zamjenjivao sve druge prostorno-planske dokumente. Krajem 1980-ih pristupilo se izradi izmjena i dopuna Plana, no procedura njihova usvajanja zaustavljena je početkom rata (IOS i PMZUS, Županijska skupština, SV 04/96, 03/99). Prema planiranim izmjenama i dopunama bila su određena tri glavna područja s gravitacijskim utjecajima središnjih naselja: Drniša (kao manjega nadlokalnog središta) te Unešića i Oklaja kao lokalnih središta. Manja lokalna središta su Siverić, Širitovci i Gradac u području Drniša (Općina Drniš, OKIZP: grafički prilozi, 1993., prema PP općine Drniš - izvod: karta sustava naselja). Za grad Drniš od 1986. godine na snazi je bio Generalni urbanistički plan, kao i nekoliko provedbenih urbanističkih planova.

Prostorni plan općine Knin izrađen je 1989. i vrijedan je dokument s prikazom stanja u prostoru i planskih postavki, iako je procedura usvajanja poremećena početkom rata. Područje općine u planu se promatra kroz središnji razvijeniji dio (grad Knin i naselja koja gravitiraju Krki i njezinim pritocima) i nerazvijeniji dio koji obuhvaća Bukovicu na zapadu i Podinarje na istoku. Društveno-ekonomski razvoj nakon Drugoga svjetskog rata kanalizirali su procesi industrijalizacije, deagrarizacije i deruralizacije, ali i problemi emigracije i smanjenja broja stanovnika općine. Došlo je do zapuštanja poljoprivrednoga zemljišta, izgradnje uz prometnice, prenamjene plodnih površina u građevinsko zemljište i bespravne izgradnje, posebno u samom Kninu, Kistanjama i prigradskim naseljima. Do izražaja su došle dnevne migracije stanovništva u radne centre: Knin i veća priobalna središta (Prostorni plan općine Knin [PPOK], 1989.). Osnovu daljnjega razvoja prema planu čine prirodni resursi; razvoj postojećih gospodarskih struktura, poljoprivredne proizvodnje i industrijskih grana komplementarnih jadranskom području, uz bolje korištenje povoljnoga prometnogeografskog položaja - "Kninskih vrata" ili "Vrata Dalmacije"11. Planiran je i policentrični sustav središnjih naselja i razvoj urbanih funkcija radi demografske stabilizacije i ravnomjernijega razvitka područja općine: subregionalno općinsko središte (Knin), važnije lokalno središte (Kistanje), lokalna središta (Zvjerinac i Strmica u Kosovom Polju i području oko Butišnice, Kijevo u Vrličko-cetinskoj krajini, Ervenik i Đevrske na vapnenačkoj zaravni) i pomoćna središnja naselja (Plavno, Golubić, Orlić, Radučić, Pađene, Polača, Žagrović i Biovičino Selo; po potrebi i dr.) (PPOK, 1989.).

Za grad Knin izrađen je Generalni urbanistički plan 1975. godine, kao i niz provedbenih urbanističkih planova u ovom razdoblju (tablica 3.). Međutim, ni za jedno drugo naselje u općini nisu izrađeni urbanistički planovi. Politika razvoja je u svakom pogledu favorizirala grad Knin, što je vidljivo u planskim dokumentima; što je rezultiralo neravnomjernim razvojem područja općine (Općina Knin, OKIZP, 1993.).

11 Ekonomski razvoj trebao bi se zasnivati na dvojnim domaćinstvima (uglavnom kombinacijom industrije i poljoprivrede ili usluga i poljoprivrede), malim proizvodnim pogonima, većim gospodarskim organizacijama, ali i individualnim poduzetnicima (PPOK, 1989.). 
Od 1983. (SV 23/83) godine na snazi je bila i Odluka o građevinskom području za područje Općine Knin.

Područje općine Šibenik bilo je relativno dobro pokriveno prostorno-planskom dokumentacijom, no bez jedinstvenoga općinskog plana. Na snazi je bio niz odluka o građevinskim područjima koje su ga donekle zamijenile. I bez obzira na pokrivenost prostora GUP-ovima i UP-ovima (Zlarin, Murter-Pirovac, Primošten-Rogoznica, Tribunj-Vodice-Srima) te velikim brojem provedbenih planova - njih čak 68 izrađeno je i doneseno za područje općine Šibenik u drugom razdoblju (tablica 3.), atraktivnost područja uz neadekvatnu zakonsku regulativu u sprječavanju bespravne izgradnje rezultirala je izgradnjom 6000 - 7000 takvih objekata do početka 1990ih, uz značajnu devastaciju prostora. Širok zaštitni obalni pojas utvrđen je prema važećem Zakonu s ciljem zaštite prostora od neplanske gradnje; no kako su iz njega bila izuzeta gotovo sva građevinska područja, to je omogućilo stihijsku izgradnju u građevinskim zonama koje nisu bile dodatno zaštićene niti regulirane provedbenim planovima (Općina Šibenik, OKIZP, 1993.). Treba napomenuti da je Šibenik tek 1988. među zadnjima u Hrvatskoj izradio GUP, nakon priprema koje su s prekidima trajale gotovo dva desetljeća. Gotovo trideset godina planeri su pokušavali riješiti krizu prostornoga širenja grada, no njihovi argumenti i rješenja padali su u vodu suočeni s dominantnim industrijskim razvojnim konceptom (Poljičak, 1995.).

Prostorni plan općine Šibenik (prijedlog) izrađen je krajem 1980-ih godina, i premda nije usvojen, značajan je dokument i osnova za daljnje razvojne koncepcije ovoga područja. Općina Šibenik ubrajala se među razvijene južnohrvatske općine. Međutim, Šibenik kao regionalno središte uslijed svoje specijaliziranosti na aluminijsku industriju i zaostajanja za regionalnim tokovima i potrebama, polagano je gubio na značenju. Knin i Drniš kao središta općina sve više su se usmjeravali prema drugim južnohrvatskim središtima. Prostorni razvoj općine obilježavala je i naglašena emigracija iz zagorskoga dijela te s otoka prema obalnim središtima, u općini i izvan nje (Prostorni plan općine Šibenik [PPOŠ], 1990.). Koncepcija razvoja u prostoru temeljila se na težištima razvoja s pet prostornih cjelina i središtima: Šibenik (uže područje), Tijesno (danas Tisno), Vodice, Skradin i Primošten ${ }^{12}$. U skladu s komparativnim prednostima u priobalnom pojasu te na otocima, predviđene su poljoprivredne, ribolovne, turističke i dr. uslužne djelatnosti; u zagorskom dijelu poljoprivreda i mala privreda, a u okviru širega područja grada Šibenika industrija, promet, trgovina te usluge. Murter, Pirovac (Tijesno); Zaton, Čista Mala (Vodice); Bribir (Skradin); Lozovac, Perković-Sitno Donje (Šibenik) i Rogoznica (u području Primoštena) predviđeni su kao pomoćna središnja naselja u pojedinim težištima razvoja. Kao naselja s pojedinačnim uslužnim funkcijama na otocima predviđeni su Betina, Jezera, Zlarin, Prvić Luka, Prvić Šepurine, Kaprije i Žirje, a u Zagori Široke, Bratiškovci te druga, po potrebi. Na ovaj način željelo se utjecati na ravnomjernu prostorno-funkcional-

12 Po obilježjima podjele rada težišta razvoja podijeljena su na ona u kojima je prevladavala turističko-poljoprivredna komponenta razvoja (Tijesno, Vodice i Primošten), ono u kojem je prevladavala industrijska komponenta (Šibenik), te ono u kojem je prevladavala poljoprivreda (Skradin) (PPOŠ, 1990.). 
nu organizaciju i uspostavljanje razvojne ravnoteže te tako stabilizirati demografski razvoj (PPOŠ, 1990.).

\subsection{Razdoblje 1992. - 2012.}

\section{Državna i regionalna razina}

Strategija prostornog uređenja Republike Hrvatske temeljni je dokument Države za usmjeravanje razvoja u prostoru (Zakon o prostornom uređenju i gradnji, NN 76/07). Izrađena je 1997. godine. Prema Strategiji stanje okoliša prije 1991. bilo je na granici zadovoljavajućega uz lokalne pojave težega ugrožavanja prostora. Dotadašnji razvoj u prostoru, vidljiv i na području Šibensko-kninske županije, obilježen je velikim regionalnim razlikama, neiskorištenošću resursa, neprimjerenom prometno-razvojnom (posavski koridor potpuno prometno definiran i izgrađen, a pravci S-J tehnički i funkcionalno nedostatni) i gospodarskom orijentacijom (često jednofunkcionalna), izrazitim useljavanjem u gradove i zapuštanjem ruralnih prostora, te prostora uz državnu granicu. Nadalje, prisutne su pojave neracionalnoga korištenja prostora i zauzimanja velikih površina za gradnju širenjem naselja i industrijskih zona na kvalitetnim poljoprivrednim površinama, kao i nekvalitetnom i masovnom gradnjom na obali mora (u velikom dijelu bespravnom). Ograničavajući faktor postale su velike društveno-ekonomske promjene u razdoblju tranzicije, ratne posljedice, negativna demografska kretanja, tehnološko zaostajanje infrastrukturnih i gospodarskih sustava, itd.

Glavni prostorno-razvojni ciljevi odnose se na održiv, uravnotežen i policentričan razvoj (osobito funkcionalnim jačanjem srednjih i manjih gradova i lokalnih središta, ${ }^{13}$ te usporavanjem rasta velikih gradova) uz unaprjeđenje infrastrukturne opremljenosti; zatim povećanje kvalitete prostora i okoliša; a među opće ciljeve sada se ubraja i europska integracija. Prema Strategiji sustav središnjih naselja - razvojnih žarišta treba činiti mreža s oko 650 - 750 gradova i važnijih naselja u urbaniziranom i ruralnom području. Osim postojeće veze istok - zapad, treba osnažiti pravce sjeverozapad - jugoistok i sjever - jug, te podravski koridor.

Program prostornog uređenja Republike Hrvatske [PPURH] utvrđuje mjere i aktivnosti za provođenje Strategije, i određuje temeljne kriterije prostornoga uređenja na svim razinama. Projekcije su napravljene do 2015. godine, s prioritetima do 2005. Prioriteti za ostvarivanje zadaća prostornoga uređenja prepoznatljivi su u grafičkim prilozima. ${ }^{14} \mathrm{Na}$ području Šibensko-kninske županije Šibenik se promatra kao veće regionalno i veće razvojno središte, Knin kao regionalno (i srednje razvojno) sredi-

13 Ocjenjuje se nerealnim poticati razvoj i obnovu svih naselja, već se smatra potrebnim izdvojiti prioritetna lokalna središta u kojima će se stvoriti nužan stupanj funkcionalne opremljenosti i koncentracije stanovništva (SPURH, 1997.).

14 Predviđa se i izrada Prostornoga plana područja hrvatskoga Jadrana (u kategoriji PPPPO) na kojem bi se temeljilo integralno upravljanje obalnim područjem (PPURH, 1999.). 
šte, Vodice su se istaknule kao manje regionalno središte (manje razvojno središte slabije razvijenosti), dok su Drniš, Skradin i Murter područna središta (mala razvojna središta). Sva ostala općinska središta su lokalna središta (inicijalna razvojna središta) (PPURH, 1999.). Uočljivo je da je ovakav sustav središnjih naselja posljedica novih odnosa u prostoru te nove upravno-teritorijalne organizacije s većim brojem općina i gradova kao jedinica lokalne samouprave, u odnosu na nekadašnje tri velike općine i njihova središta.

Zavod za prostorno uređenje (prvotno Šibenske županije), odgovoran za izradu prostornoga plana Županije, osnovan je 1995. godine. Kako je postojao problem formiranja nove stručne ekipe koja bi se sustavno bavila izazovima prostornoga planiranja ovoga područja, kao suradnik pri izradi županijskoga prostornog plana odabrana je privatna tvrtka (Lučev, 2001.).

Prostorni plan Šibensko-kninske županije dovršen je 2002., uz kasnije izmjene i dopune. Njime su razrađena načela i ciljevi prostornoga uređenja te organizacija, zaštita, korištenje i namjena prostora (PPŠKŽ, Knjiga 2, 2007.). U skladu s obilježjima prostora te već postojećim funkcionalno-gravitacijskim obilježjima, Županija se u planu dijeli na veće prostorno-funkcionalne cjeline (ujedno i razvojna područja): Primorje i kontinentalno područje (Zagora). Primorje uključuje prostor bivše općine Šibenik - obalno i otočno područje te zaobalni poljoprivredni prostor, dok kontinentalno područje uključuje drnišku Zagoru (bivša općina Drniš) i kninsku Zagoru (bivša općina Knin). Naglašava se da je razvoj bivših općina bio izrazito monocentričan, s dominacijom općinskih središta u kojima su bili koncentrirani stanovništvo i radna mjesta. Samo na prostoru općine Šibenik ovaj je proces bio nešto manje izražen zbog razvoja obalnih naselja pod utjecajem turizma (PPŠKŽ, Knjiga 1, 2002.). Suvremeni ustroj gradova i općina te njihova središta uglavnom odgovaraju središnjim naseljima utvrđenima u sustavu naselja ranije dokumentacije.

Zaključeno je da se prostorno-planskom dokumentacijom često udovoljavalo željama različitih subjekata u prostoru neracionalnim zauzimanjem prostora za građevinska područja; područja utvrđivana za gradnju i razvoj naselja (prvenstveno stanovanja) u depopulacijskim, nerazvijenim područjima Županije uglavnom su ostajala neizgrađena osim uz postojeću infrastrukturu (prometnicu). S druge strane, bez obzira na relativno velika planirana građevinska područja na obalnom području, nije posvećena dovoljna pažnja nadzoru gradnje i zaštiti prostora. Nije se sustavno provodilo uređenje građevinskoga zemljišta (od detaljnih planova pa do opremanja komunalnom infrastrukturom) pa je nastala uglavnom neplanska izgradnja (uz znatan dio bespravne izgradnje), koja nije bila prilagođena tradicijskim vrijednostima područja. U primorskom dijelu Županije područja za gradnju i razvoj naselja tako su uglavnom zauzeta građevinama povremenoga stanovanja ${ }^{15}$ (PPŠKŽ, Knjiga 1, 2002.).

S obzirom na izrazitu razvojnu neravnotežu, u ciljevima prostornoga razvoja ponovno se ističe potreba jačanja policentričnoga sustava naselja; bolje infrastrukturne

15 Opačić (2009.) analizira razvojnu dinamiku i prostorni raspored vikendaštva u priobalnom dijelu Hrvatske nakon Drugoga svjetskog rata. 
opremljenosti; potpunijega korištenja geoprometnog položaja, postojećih gospodarskih kapaciteta i ostalih proizvodnih potencijala te posebno razvoja turizma i njemu komplementarnih djelatnosti. Vezano za područja s ograničenjima u razvoju koja su definirana Strategijom PU RH, predložene su mjere za tipove prisutne u Županiji (u velikoj mjeri se preklapaju): područja uz državnu granicu, brdsko-gorska, ratom zahvaćena područja, ruralna područja i otoci (PPŠKŽ, Knjiga 1, 2002.).

Do 2015. Planom se predviđa razvoj sustava središnih naselja sa Šibenikom kao većim regionalnim središtem. Regionalna središta su Knin, Drniš i Vodice, a Skradin, Pirovac, Tisno, Murter, Primošten, Rogoznica, Tribunj, Oklaj, Gradac, Unešić, Biskupija, Civljane, Ervenik, Kijevo i Kistanje su lokalna središta. Naselja Bilice, Brodarica, Dubrava (kod Šibenika), Vrpolje, Lozovac, Zaton, Perković, Piramatovci, Čista Velika, Široke, Drinovci, Pakovo Selo, Siverić, Strmica i Đevrske su manja lokalna središta - pomoćna središnja naselja. Primjećuje se da su u odnosu na Strategiju i Program prostornoga uređenja RH prisutna odstupanja u sustavu središnjih naselja; s obzirom na težnju policentričnom razvoju te njihovu dosadašnju ulogu u prostoru, i Drniš i Vodice u sustavu središnjih naselja kategorizirani su kao regionalna središta.

U obuhvatu Šibensko-kninske županije nalaze se nacionalni parkovi "Krka" i "Kornati" te vrlo malim dijelom parkovi prirode "Velebit" i "Vransko jezero". U razdoblju nakon 1992. godine donesen je novi prostorni plan za NP "Kornate" (2003.) i prvi prostorni plan za PP "Vransko jezero" (2012.). U slučaju NP "Krka” još uvijek je na snazi plan iz 1990., a u tijeku je izrada novoga. U izradi je i prvi prostorni plan PP "Velebit".

\section{Lokalna razina}

Urbanistički institut Hrvatske izradio je 1993. Osnovu korištenja i zaštite prostora za svaku od bivših općina: Drniš, Knin i Šibenik ${ }^{16}$. Osnove su analitički dokumenti koji sadrže vrijedan prikaz dotadašnje prostorno-planske dokumentacije ${ }^{17}$, stanja razorenosti ovih područja, kao i ocjenu mogućnosti prostornoga razvoja te smjernice za korištenje i zaštitu prostora općina. S obzirom na izmijenjenu upravno-teritorijalnu organizaciju Republike Hrvatske od 1992. te Zakon o PU iz 1994. koji navodi obvezu izrade prostornih planova jedinica lokalne samouprave, u ovome razdoblju izrađuju se planovi općina i gradova, kao i planovi niže razine (tablica 4.). Neposredno nakon Domovinskoga rata donesene su izmjene i dopune PP (bivše) općine Drniš za područje Grada Drniša te općina Promina, Ružić i Unešić, dok su za područja bivših općina Šibenik i Knin na snazi i dalje bile odluke o građevinskim područjima, donošene od 1983.

16 1992. godine donesena je Uredba o prostornom uređenju u ratom zahvaćenim područjima Republike Hrvatske (NN 44/92, NN 77/92).

17 Na dostupnost prostorno-planske dokumentacije utjecala su ratna zbivanja na području ovih općina. 
Tablica 4.

Prostorni planovi za područje današnje Šibensko-kninske županije izrađeni 1992. - 2012., po razinama

\begin{tabular}{|c|c|c|c|}
\hline \multicolumn{4}{|c|}{ VRSTA I NAZIV PLANA /DONOŠENJE PLANA/ } \\
\hline \multicolumn{4}{|c|}{ DRZ̈AVNA I REGIONALNA RAZINA } \\
\hline \multicolumn{4}{|c|}{ Strategija prostornog uređenja RH /1997./; Program prostornog uređenja RH /NN 50/99/; } \\
\hline \multicolumn{4}{|c|}{ PP NP "Kornati" /NN 118/03/; PP PP "Vransko jezero" /NN 58/12/; } \\
\hline \multicolumn{4}{|c|}{ PP Šibensko-kninske županije /SV 11/02, 10/05, 03/06, 05/08, 06/12, 09/12/. } \\
\hline \multicolumn{4}{|c|}{ LOKALNA RAZINA } \\
\hline \multicolumn{4}{|c|}{ Osnova zaštite i korištenja prostora (bivše) općine Drniš, 1993. /ne donosi se/; } \\
\hline \multirow{4}{*}{ GRAD DRNIŠ } & \multirow{2}{*}{\multicolumn{3}{|c|}{$\begin{array}{l}\text { PP općine Drniš, Izmj. i dop. za područje Grada Drniša /SV 12/97/; PPU Grada } \\
\text { Drniša /SV 01/00, 07/06, 02/08,08/12/; }\end{array}$}} \\
\hline & & & \\
\hline & \multirow{2}{*}{$\begin{array}{l}\text { DPU dijela zone V-B, Drniš-Balek /SV } \\
\text { 03/97/; } \\
\text { UPU grada Drniša /SV 12/02, 11/06, 06/09, } \\
\text { 16/09/; }\end{array}$} & $\begin{array}{l}\text { DPU groblja Sveti } \\
\text { Ivan - Badanj /SV } \\
12 / 02,07 / 08 / ;\end{array}$ & $\begin{array}{l}\text { UPU gosp. zone } \\
\text { Radonić } / \text { SV } 14 / 09 \\
14 / 10,02 / 11 / ;\end{array}$ \\
\hline & & $\begin{array}{l}\text { DPU st. zone Kalun } \\
\text { u Drnišu /SV 06/09, } \\
\text { 16/09/; }\end{array}$ & $\begin{array}{l}\text { UPU gosp. zone } \\
\text { Brištane /SV 01/12/; }\end{array}$ \\
\hline 0. PROMINA & \multicolumn{3}{|c|}{$\begin{array}{l}\text { PP općine Drniš, Izmj. i dop. za područje Općine Promina /SV 03/98, 18/98/; } \\
\text { PPU Općine Promina /SV 05/09/; }\end{array}$} \\
\hline 0. RUŽIĆ & \multicolumn{3}{|c|}{ PPU Općine Ružić /SV 04/04, 07/12/; } \\
\hline 0. UNEŠIĆ & \multicolumn{3}{|c|}{$\begin{array}{l}\text { PP općine Drniš, Izmj. i dop. za područje Općine Unešić /SV 12/97/; PPU } \\
\text { Općine Unešić /SV 10/07/. }\end{array}$} \\
\hline \multicolumn{4}{|c|}{ Osnova zaštite i korištenja prostora (bivše) općine Knin, 1993. /ne donosi se/; } \\
\hline \multirow{5}{*}{ GRAD KNIN } & \multicolumn{3}{|c|}{ PPU Grada Knina /SV 05/03, 05/12/; } \\
\hline & \multicolumn{3}{|c|}{ GUP grada Knina /SV 11/99, 05/05, 10/11/; } \\
\hline & $\begin{array}{l}\text { DPU "Novo naselje" - Golubić /SV 03/03, } \\
\text { 05/06/; }\end{array}$ & $\begin{array}{l}\text { DPU prostora ist. } \\
\text { od gosp, zone } \\
\text { "Luzine" u Kninu / } \\
\text { sv } 11 / 08 / ;\end{array}$ & $\begin{array}{l}\text { UPU "Kod Doma u } \\
\text { Vrpolju" /SV 13/09/; }\end{array}$ \\
\hline & $\begin{array}{l}\text { DPU "Novi centar" u Kninu /SV 09/07, } \\
\text { 03/09/; }\end{array}$ & $\begin{array}{l}\text { DPU gradskog } \\
\text { groblja u Kninu /SV } \\
\text { 11/08/; }\end{array}$ & $\begin{array}{l}\text { UPU "Drpina } \\
\text { Glavica", mješovita } \\
\text { namjena /SV 01/10/; }\end{array}$ \\
\hline & $\begin{array}{l}\text { DPU sjev. gosp. zone (I3) - ist. dio /SV } \\
\text { 09/07/; }\end{array}$ & $\begin{array}{l}\text { UPU "Više Sv. } \\
\text { Jakova" /SV 13/09/; }\end{array}$ & $\begin{array}{l}\text { UPU neizgradeni dio } \\
\text { gosp. zone "Lužine" } \\
\text { I1(Preparandija) /SV } \\
01 / 10 / ;\end{array}$ \\
\hline 0. BISKUPIJA & \multicolumn{3}{|c|}{ PPU Općine Biskupija /SV 02/06, 04/09, 11/09/; } \\
\hline 0. CIVLJANE & \multicolumn{3}{|c|}{ PPU Općine Civljane /SV 19/06/; } \\
\hline \multirow{2}{*}{ 0. ERVENIK } & \multicolumn{3}{|c|}{ PPU Općine Ervenik /SV 10/07; 09/11/; } \\
\hline & \multicolumn{3}{|c|}{ UPU poduzetničke zone Pađene u Općini Ervenik /SV 07/12/; } \\
\hline 0. KIJEVO & \multicolumn{3}{|c|}{ PPU Općine Kijevo /SV 13/05/; } \\
\hline \multirow{2}{*}{ 0. KISTANJE } & \multicolumn{3}{|c|}{ PPU Općine Kistanje /SV 03/06/; } \\
\hline & \multicolumn{3}{|c|}{ DPU "Kistanje-centar" naselja Kistanje /SV 21/01/. } \\
\hline \multicolumn{4}{|c|}{ Osnova zaštite i korištenja prostora (bivše) općine Šibenik, 1993. /ne donosi se/; } \\
\hline \multirow{9}{*}{ GRAD ŠIBENIK } & \multicolumn{3}{|c|}{ PPU Grada Šibenika /SV 03/03, 09/03, 10/04, 11/07, SG 05/12/; } \\
\hline & $\begin{array}{l}\text { GUP grada Šibenika - Autentično tun } \\
01 / 01,05 / 02,05 / 06, \mathrm{SG} 06 / 08 / ;\end{array}$ & čenje; Izmj. i dop. & V 03/96; 08/99, \\
\hline & $\begin{array}{l}\text { PUP lucko-pretovarne zone Sibenik - } \\
\text { izmj. i dop } / \text { SV } 02 / 95, \text { SG 01/08/; }\end{array}$ & $\begin{array}{l}\text { DPU Subićevac- } \\
\text { Jamniak } / \text { SV } 16 / 06 / ; \ldots\end{array}$ & $\begin{array}{l}\text { DPU sport. luke } \\
\text { Pekovac } / \mathrm{SG} .09 / 08 / ; \ldots\end{array}$ \\
\hline & PUP Baldekin I - izmj. i dop. /SV 03/96/; & $\begin{array}{l}\text { Kuline - Mandalina } \\
\text { KSV } 13 / 07 / \text {. }\end{array}$ & $\begin{array}{l}\text { turizma i sport. luke } \\
\text { Vrnaža u Sibeniku / } \\
\text { SG } 10 / 08 / \text { : }\end{array}$ \\
\hline & $\begin{array}{l}\text { Autent. tumačenje izmj. i dop. PUP-a st. i } \\
\text { rekreac. zone Subićevac /SV 09/98/; }\end{array}$ & $\begin{array}{l}\text { UPU gosp. zone } \\
\text { Jelovače u Zatonu / } \\
\text { SV 17/07/: }\end{array}$ & $\begin{array}{l}\text { UPU Zlarina } / \text { SG } \\
\text { 02/09/; }\end{array}$ \\
\hline & $\begin{array}{l}\text { DPU gosp. zone II/4.3. Ražine Gornje /sV } \\
06 / 03,04 / 07 / ;\end{array}$ & $\begin{array}{l}\text { UPU gosp. zone } \\
\text { Mrdakovica u } \\
\text { Zatonu /SV } 17 / 07 /\end{array}$ & $\begin{array}{l}\text { UPU spoot.-rekreac. } \\
\text { zone i luke naut. } \\
\text { turizma Dobri Dolac } \\
\text {-Zaton } / \text { SG } 02 / 09 / \text {. }\end{array}$ \\
\hline & $\begin{array}{l}\text { UPU gosp. zone "Podi" /SV 09/04, SG } \\
\text { 01/08/; }\end{array}$ & $\begin{array}{l}\text { PUP st.-rekreac. } \\
\text { zone Subićevac } \\
\text { - izmj. i dop. /SG }\end{array}$ & $\begin{array}{l}\text { UPU Most - Šbenik } \\
\text { /SG 09/10/; }\end{array}$ \\
\hline & $\begin{array}{l}\text { PUP st. naselja Meterize - izmj. i dop. /SV } \\
05 / 06, \text { SG 08/08/; }\end{array}$ & $\begin{array}{l}\text { DPU zone } \\
\text { mješovite namjene } \\
\text { pretežito poslovne } \\
\text { II/2.8.Njivice /SG } \\
\text { O2/08.SG 08/10/. }\end{array}$ & \\
\hline & $\begin{array}{l}\text { DPU Šubićevac - ex Poliplast /SV 16/06, } \\
\text { 03/07, SG 07/08, stavljanje van snage 10/11/; }\end{array}$ & $\begin{array}{l}\text { UPT naselja } \\
\text { Brodarica /SG 08/08, } \\
\text { 08/12/; }\end{array}$ & \\
\hline
\end{tabular}




\begin{tabular}{|c|c|c|c|}
\hline \multirow[b]{2}{*}{ GRAD SKRADIN } & \multicolumn{3}{|c|}{ PPU Grada Skradina /SV 06/01, 06/04 06/08/; } \\
\hline & UPU grada Skradina /SV 16/02, 04/03/; & $\begin{array}{l}\text { UPU zone mješovite } \\
\text { namjene "Kosa" } \\
\text { Ićevo /SV 14/06/; }\end{array}$ & $\begin{array}{l}\text { DPU prost. jedinica } \\
11 \text { i } 12 \text { (pristanišno- } \\
\text { rekreac. zona) u } \\
\text { Skradinu /SV } 01 / 08 / \text {; }\end{array}$ \\
\hline \multirow{3}{*}{ GRAD VODICE } & \multicolumn{3}{|c|}{ PPU Grada Vodica /SV 13/97, 15/02, 07/07/; PPU Grada Vodica /SV 14/06, 11/07/; } \\
\hline & $\begin{array}{l}\text { PUP st. zone Blata - Pudarice - izmj. i } \\
\text { dop. /SV 02/96/; }\end{array}$ & $\begin{array}{l}\text { UPU ind. zone Čista } \\
\text { u Gradu Vodice } / \mathrm{SV} \\
02 / 08 / ;\end{array}$ & $\begin{array}{l}\text { DPU groblja Srima / } \\
\text { SV 04/11/; }\end{array}$ \\
\hline & $\begin{array}{l}\text { PUP tur. zone Punta - Vodice - izmj. i } \\
\text { dop. /SV 08/03/; }\end{array}$ & $\begin{array}{l}\text { UPU naselja Vodice } \\
\text { i Srima /SV } 10 / 08, \\
12 / 09 / ;\end{array}$ & \\
\hline \multirow[b]{2}{*}{ 0. BILICE } & \multicolumn{3}{|l|}{ PPU Općine Bilice /SV 09/06, 01/10/; } \\
\hline & $\begin{array}{l}\text { DPU - zona središnjih sadržaja Bilica /SV } \\
07 / 08,01 / 09,11 / 10 / \text {; }\end{array}$ & $\begin{array}{l}\text { UPU - Uvale Stubalj } \\
\text { /SV } 04 / 09,14 / 10 \\
01 / 11 / ;\end{array}$ & $\begin{array}{l}\text { UPU Stubalj I /SV } \\
04 / 10 / ;\end{array}$ \\
\hline 0. MURTER - K. & \multicolumn{3}{|c|}{ PPU Općine Murter /SV 02/04, 03/04, 13/04, 11/05, 04/06, 04/07, 12/08, 05/11/; } \\
\hline \multirow[b]{2}{*}{ 0. PIROVAC } & \multicolumn{3}{|l|}{ PPU Općine Pirovac /SV 20/06, 09/09/; } \\
\hline & $\begin{array}{l}\text { PUP tur. zone T1 i T2 - Pirovac - izmj. i } \\
\text { dop. /SV 16/98/; }\end{array}$ & $\begin{array}{l}\text { PUP dijela centra } \\
\text { Pirovca C } 3 \text { - izmj. } \\
\text { i dop.; stavljanje } \\
\text { van snage /SV } 15 / 02 ; \\
02 / 11 / \text {; }\end{array}$ & $\begin{array}{l}\text { UPU luke naut. } \\
\text { turizma - marina } \\
\text { Pirovac /SV 02/11/; }\end{array}$ \\
\hline \multirow{4}{*}{ 0. PRIMOŠTEN } & \multicolumn{3}{|c|}{ PPU Općine Primošten /SV 13/05, 10/08, 05/11, 10/11/; } \\
\hline & $\begin{array}{l}\text { UPU ugostit.-tur. zone Marina Lučica / } \\
\text { SV 08/10/; }\end{array}$ & $\begin{array}{l}\text { UPU naselja Bilo / } \\
\text { SV 13/10/; }\end{array}$ & $\begin{array}{l}\text { UPU luke naut. } \\
\text { turizma marine } \\
\text { Kremik /SV 09/11/. }\end{array}$ \\
\hline & $\begin{array}{l}\text { UPU sport. rekreac. zone Kremik R1/ } \\
\text { SV } 12 / 10 / ;\end{array}$ & $\begin{array}{l}\text { UPU Primošten } \\
\text { Burnji "Sarićevi" /SV } \\
17 / 10 / \text {; }\end{array}$ & $\begin{array}{l}\text { UPU zone "Uz } \\
\text { vojske" /SV 10/11/; }\end{array}$ \\
\hline & $\begin{array}{l}\text { UPUU ugostit.-tur. Zone Aurora-zona T2 } \\
\text { - tur. naselje /SV 13/10/: }\end{array}$ & $\begin{array}{l}\text { UPU tur. zone } \\
\text { Raduča /SV } 08 / 11 / \text { : }\end{array}$ & \\
\hline \multirow[b]{2}{*}{ 0. ROGOZNICA } & \multicolumn{3}{|c|}{ PPU Općine Rogoznica /SV 05/09, 01/10, 03/10, 06/10, 06/11, 09/12/; } \\
\hline & $\begin{array}{l}\text { DPU tur. zone Gornji Muli - Rogoznica / } \\
\text { SV 22/01/; }\end{array}$ & $\begin{array}{l}\text { UPU } 6 \text { - Poslovna } \\
\text { zona "Krušcica" /SV } \\
03 / 12 /\end{array}$ & \\
\hline \multirow{4}{*}{ 0. TISNO } & \multicolumn{3}{|c|}{ PPU Općine Tisno /SV 01/07, 14/09/; } \\
\hline & DPU mjesne lučice Betina /SV 15/01/; & $\begin{array}{l}\text { UPU tur. ugostit. } \\
\text { zone Mišji Vrh /SV } \\
14 / 10 / ;\end{array}$ & $\begin{array}{l}\text { UPU tur.-ugostit. } \\
\text { zone Prisliga - } \\
\text { Jazine /SV 06/11/; }\end{array}$ \\
\hline & $\begin{array}{l}\text { DPU luke naut. turizma u uvali Luka - } \\
\text { Tisno /SV 12/07/; }\end{array}$ & $\begin{array}{l}\text { UPU zona luke } \\
\text { posebne namjene } \\
\text { - marina s } \\
\text { brodogradilištem } \\
\text { SV } 16 / 10 /\end{array}$ & $\begin{array}{l}\text { UPU obalno } \\
\text { područje naselja } \\
\text { Betina - Pačipolje } \\
\text { SV 11/11/; }\end{array}$ \\
\hline & $\begin{array}{l}\text { UPU (UPU-17) ugostit.-tur. zone } \\
\text { Rastovac u Tisnom /SV 14/10/; }\end{array}$ & $\begin{array}{l}\text { UPU kampa } \\
\text { Modrave (uvala } \\
\text { Lučica) /SV 16/10, } \\
04 / 11 / ;\end{array}$ & $\begin{array}{l}\text { UPU sjev. dio } \\
\text { naselja Jezera /SV } \\
11 / 11 / ;\end{array}$ \\
\hline \multirow{2}{*}{ 0. TRIBUNJ } & \multicolumn{3}{|l|}{ PPU Grada Vodica /SV 14/06, 03/11/; } \\
\hline & \multicolumn{3}{|l|}{ UPU naselja Tribunj /SV 03/11, 07/11/. } \\
\hline
\end{tabular}

Napomena 1: Kod vrste i naziva planova korištene su skraćenice: PPU - prostorni plan uređenja, GUP - generalni urbanistički plan, GPU - generalni plan uređenja, UPU - urbanistički plan uređenja, PUP provedbeni urbanistički plan, DPU - detaljni plan uređenja. Puni nazivi navođeni su ako skraćenica ne bi bila dovoljno jasna.

Napomena 2: kao za tablicu 2.

Napomena 3: Unutar kosih crta (//), kada je to bilo moguće, navedeni su brojevi Službenoga vjesnika općine Drniš, Knin i Šibenik, tj. Službenog vjesnika Županije Šibenske (od 1994.) te naposljetku Službenoga vjesnika Šibensko-kninske županije (od 1997.) s odlukama o donošenju pojedinih planova. Od 2008. za Grad Šibenik odluke se objavljuju u Službenom glasniku Grada Šibenika (SG).

Izvor: prikupljena prostorno-planska dokumentacija; IOS i PMZUS Šibensko-kninske županije, SV Šibensko-kninske županije 03 od 1999., 02 od 2007.; SV Šibensko-kninske županije 2007. - 2012.; SG Grada Šibenika 2008. - 2012.; Grad Šibenik, Prostorni planovi na snazi.

Prvi prostorni planovi uređenja nove generacije doneseni su za Grad Vodice (1997.) te Grad Drniš (2000.), a uslijedile su sve ostale jedinice lokalne samouprave (gradovi 
su prednjačili pred općinama). Općine Civljane, Ervenik, Kistanje i Promina ubrojene su u općine koje mogu donijeti PPU smanjenoga sadržaja. ${ }^{18}$

Problem koji se javlja na razini općina/gradova u Hrvatskoj općenito je neracionalno gospodarenje i parcijalno gledanje na prostor. Jedinice lokalne samouprave imaju ovlasti gospodarenja svojim prostorom, pri čemu mnoge za to nemaju financijske, tehničke ni stručne mogućnosti (Kranjčević, 2005.). Jedan od problema nedovoljno kvalitetne komunalne, zemljišne i prostorne politike jest što prostorni planovi uređenja općina i gradova često ostaju na stupnju određivanja građevinskih područja. Površine određene za gradnju veće su od potreba i mogućnosti naselja, što odražava neracionalno postupanje sa zemljištem (Kranjčević, 2005.).

Upravni gradovi, primarno njihova središnja naselja, pokriveni su generalnim urbanističkim planovima ili urbanističkim planovima uređenja te u većoj mjeri i detaljnim planovima uređenja (nekadašnjim PUP-ovima). Brojnost provedbenih planova ovdje posredno ukazuje na intenzitet aktivnosti u prostoru u čemu prednjači Grad Šibenik, a suprotan pol čine zagorske općine. Za područje Grada Šibenika u trećem razdoblju doneseno je 7 novih UPU-a te 7 novih DPU-a različitih namjena; 24 UPU-a i 6 DPU-a doneseno je za ostale gradove i općine u šibenskoj subregiji. S druge strane, 3 UPU-a i 3 DPU-a usvojena su za Grad Drniš te 4 UPU-a i 5 DPU-a za Grad Knin, 1 UPU i 1 DPU za općine u kninskoj subregiji te niti jedan za općine u drniškoj subregiji. Oko trećine provedbenih planova u drniškoj i kninskoj subregiji odnosi se na gospodarske zone kao noviju razvojnu alternativu.

\section{Učinkovitost prostornoga planiranja na području Šibensko-kninske županije}

Hrvatska ima dugu tradiciju u planiranju uređenja prostora na razini naselja i njihovih neposrednih okolica. I regionalno prostorno planiranje razmjerno je rano postalo dio planerske prakse (1960-ih). Kad se pojavilo u izradi prvoga republičkog prostornog plana i regionalnih prostornih planova imalo je razvijenu metodologiju i definirane sastavnice iz kojih je nastajao završni dokument plana. Planovi su imali široku osnovu stručnih studija i analiza (Mattioni, 2003.). U prikazanim planovima republičke/državne i (makro)regionalne razine koji su izrađivani od 2. polovice 20. stoljeća, a napose nakon osamostaljenja Hrvatske, prisutna je težnja jačanja razvojne okosnice duž jadranske obale koja bi mogla parirati kontinentalnoj okosnici, odnosno općenito pravaca sjever-jug kao pandana dugo preferiranim pravcima istok-zapad. Šibenik je obično promatran kao regionalni, Knin mezoregionalni, a Drniš mikroregionalni centar u okviru Dalmacije. Pritom je stalno isticana težnja policentričnoga urbanog sustava, odnosno policentričnoga razvoja, a ovim centrima (kao i drugim dalmatinskim središtima) dodjeljivana uloga aktiviranja slabo razvijenih područja dalmatinskoga zaleđa, Like pa i zapadne Bosne i Hercegovine (tablica 5.).

18

prema Odluci o općinama koje mogu donijeti prostorni plan uređenja općine sa smanjenim sadržajem (NN 163/04) te Pravilniku o općinama koje mogu donijeti prostorni plan uređenja općine smanjenog sadržaja i sadržaju, mjerilima kartografskih prikaza i obveznim prilozima toga plana (NN 135/10). 
Tablica 5.

Obilježja prostornoga planiranja i dominantni procesi na području današnje Šibensko-kninske županije po razinama i razdobljima nakon Drugoga svjetskog rata

\begin{tabular}{|c|c|c|}
\hline $\begin{array}{c}\text { RAZDOBLJE/ } \\
\text { RAZINA }\end{array}$ & $\begin{array}{l}\text { DOMINANTNI } \\
\text { PROCESI U } \\
\text { PROSTORU }\end{array}$ & OBILJEŽJA PLANIRANJA \\
\hline $\begin{array}{c}\text { 1945. - } 1975 . \\
\text { REPUBLIČKA } \\
\text { I (MAKRO) } \\
\text { REGIONALNA }\end{array}$ & \multirow[b]{2}{*}{$\begin{array}{l}\text { - gradnja i } \\
\text { razvoj naselja na } \\
\text { jadranskoj obali } \\
\text { - industrijalizacija } \\
\text { i turistički razvoj } \\
\text { s koncentracijom } \\
\text { stanovništva u } \\
\text { priobalnom pojasu } \\
\text { - deagrarizacija } \\
\text { i emigracija iz } \\
\text { zagorskog dijela i } \\
\text { s otoka }\end{array}$} & $\begin{array}{l}\text { - zakoni o prostornom planiranju/uređenju 1961. i } 1973 . \\
\text { - izrada (makro)regionalnih prostornih planova; prvi } \\
\text { republički prostorni plan } 1974 . \\
\text { - razvoj metodologije integralnog planiranja } \\
\text { - planiranje nove razvojne okosnice u jadranskom području } \\
\text { - težnja rastu kombinacijom industrije i turizma }\end{array}$ \\
\hline $\begin{array}{c}1945 .-1975 . \\
\text { LOKALNA }\end{array}$ & & $\begin{array}{l}\text { - regulacijski planovi i osnove u počecima poslijeratnoga } \\
\text { planiranja } \\
\text { - donošenje odluka koje zamjenjuju urbanističke planove i } \\
\text { urbanističkih planova } \\
\text { - provedbu planova osiguravaju općinske službe izradom } \\
\text { urbanističkih uvjeta izgradnje na temelju provedbenih } \\
\text { planova te izdavanjem građevinskih dozvola } \\
\text { - izrada razvojnih i provedbenih planova uglavnom u } \\
\text { gradskim naseljima } \\
\text { - nerazvijene općine - poteškoće u organizaciji urbanističkih } \\
\text { službi } \\
\text { - prostorno-planska dokumentacija neujednačena s obzirom } \\
\text { na metodološki pristup, sadržaj, razvojne koncepcije i } \\
\text { usklađenost sa Zakonom iz 1973. } \\
\text { - planiranje više obilježava izrada statičnih dokumenata, a } \\
\text { manje dinamično usmjeravanje razvoja }\end{array}$ \\
\hline $\begin{array}{c}\text { 1975. - } 1992 . \\
\text { REPUBLIČKA } \\
\text { I(MAKRO) } \\
\text { REGIONALNA }\end{array}$ & \multirow{2}{*}{$\begin{array}{l}\text { - urbanizacija, } \\
\text { industrijalizacija } \\
\text { i turistički razvoj } \\
\text { s koncentracijom } \\
\text { stanovništva u } \\
\text { priobalnom pojasu } \\
\text { - deagrarizacija } \\
\text { i emigracija iz } \\
\text { zagorskog dijela i } \\
\text { s otoka } \\
\text { - monocentričan } \\
\text { razvoj općina } \\
\text { s dominacijom } \\
\text { općinskih središta, } \\
\text { posebno u } \\
\text { zagorskom dijelu } \\
\text { - Šibenik gubi } \\
\text { na značenju } \\
\text { kao regionalno } \\
\text { središte } \\
\text { - bespravna } \\
\text { izgradnja } \\
\text { uz značajnu } \\
\text { devastaciju } \\
\text { prostora }\end{array}$} & $\begin{array}{l}\text { - zakon o prostornom planiranju } 1980 . \\
\text { - pripreme i izrada PP ZO Split; drugi PP Hrvatske } 1989 . \\
\text { - izrađeni prostorni planovi za nacionalne parkove } \\
\text { - česta nepovezanost društveno-ekonomskoga i prostornoga } \\
\text { planiranja, nepoštivanje planova, ali i neracionalan pristup } \\
\text { korištenju prostora u planovima } \\
\text { - težnja optimalnom i racionalnom korištenju prostora, } \\
\text { razvoju policentričnoga sustava i jačanju primorske okosnice } \\
\text { razvoja države }\end{array}$ \\
\hline $\begin{array}{c}1975 .-1992 . \\
\text { LOKALNA }\end{array}$ & & $\begin{array}{l}\text { - općinski prostorni planovi (samo za općinu Drniš je bio } \\
\text { na snazi) } \\
\text { - težnja policentričnom razvoju jačanjem lokalnih središta } \\
\text { - brojni urbanistički planovi neravnomjerno raspoređeni u } \\
\text { prostoru } \\
\text { - neracionalno zauzimanje prostora za građevinska zemljišta } \\
\text { u prostorno-planskoj dokumentaciji u nerazvijenim } \\
\text { područjima } \\
\text { - neprovođenje sustavnoga uređenja građevinskoga zemljišta } \\
\text { u obalnom području, nedovoljan nadzor gradnje i zaštite } \\
\text { obalnoga prostora }\end{array}$ \\
\hline
\end{tabular}




\begin{tabular}{|c|c|c|}
\hline $\begin{array}{l}\text { RAZDOBLJE/ } \\
\text { RAZINA }\end{array}$ & $\begin{array}{l}\text { DOMINANTNI } \\
\text { PROCESI U } \\
\text { PROSTORU }\end{array}$ & OBILJEŽJA PLANIRANJA \\
\hline $\begin{array}{l}1992 . \text { - } 2012 . \\
\text { DRŽAVNA I } \\
\text { REGIONALNA }\end{array}$ & $\begin{array}{l}\text { - društveno- } \\
\text { ekonomske } \\
\text { promjene u } \\
\text { razdoblju tranzicije } \\
\text { - negativni } \\
\text { gospodarski i } \\
\text { demografski } \\
\text { trendovi } \\
\text { pogoršani ratnim } \\
\text { posljedicama } \\
\text { - nova, usitnjena, } \\
\text { upravno- } \\
\text {-teritorijalna } \\
\text { organizacija }\end{array}$ & $\begin{array}{l}\text { - zakoni o prostornom uređenju 1994. i } 2007 . \\
\text { - raspad velikih planerskih institucija; pad } \\
\text { interdisciplinarnosti } \\
\text { - 1995. osnovan županijski Zavod za PU - problem } \\
\text { formiranja nove stručne ekipe } \\
\text { - Strategija (1997.) i Program (1999.) prostornoga uređenja } \\
\text { RH } \\
\text { - županijski prostorni plan 2002. } \\
\text { - i dalje se teži uravnoteženom razvoju i policentričnom } \\
\text { sustavu naselja, boljoj povezanosti kvalitetnijom prometnom } \\
\text { i komunalnom infrastrukturom, zaustavljanju negativnih } \\
\text { demografskih procesa } \\
\text { - prevlast interesa kapitala i tržišta u odnosu prema prostoru } \\
\text { - pretjerana gradnja bez dovoljnoga nadzora, posebno u } \\
\text { obalnom pojasu }\end{array}$ \\
\hline $\begin{array}{c}1992 .-2012 . \\
\text { LOKALNA }\end{array}$ & $\begin{array}{l}\text { devastacije } \\
\text { prostora, } \\
\text { intenzivna gradnja } \\
\text { osobito turističkih } \\
\text { i objekata } \\
\text { sekundarnog } \\
\text { stanovanja, često } \\
\text { izvan zakona }\end{array}$ & $\begin{array}{l}\text { - nedovoljna zaštita prostora kao resursa } \\
\text { - izrada i donošenje prostornih planova gradova i općina } \\
\text { - PPU općina i gradova često usmjereni na određivanje } \\
\text { građevinskih područja } \\
\text { - brojnost provedbenih planova na području šibenske } \\
\text { subregije } \\
\text { - strukturna slabost zagorskih općina }\end{array}$ \\
\hline
\end{tabular}

Razmatrajući dominantne procese u prostoru u razdoblju nakon Drugoga svjetskog rata može se zaključiti da se u planovima prisutno nastojanje za industrijskim i turističkim razvojem pokazalo uspješnim, kako na području Primorske Hrvatske uopće, tako i današnje Šibensko-kninske županije. Međutim, uvjetovano privlačnošću obalnih središta $\mathrm{s}$ jakom industrijskom bazom ili izraženom turističkom orijentacijom, odnosno gospodarskom zaostalošću otočkoga i zagorskoga dijela (s izuzetkom Drniša i Knina kao središta rada raznovrsnijega karaktera), ovo područje suočava se s populacijskim pražnjenjem otoka i zaobalja uz sve veću koncentraciju stanovništva na obali. S obzirom i na premalu diverzifikaciju gospodarstva, tj. prejaku orijentaciju na metalurški kompleks, sam Šibenik kao regionalno središte gubio je snagu utjecaja već od kraja 1980-ih. S druge strane, planovi su često više statično konstatirali razvojne tendencije u prostoru nego dinamično utjecali na njih.

Unatoč težnjama za policentričnim razvojem jačanjem lokalnih središta, razvoj triju "velikih" općina - Drniš, Knin i Šibenik, bio je uvelike obilježen centralizacijom i koncentriranjem razvoja u općinskim središtima i dijelu obalnih naselja, što je posredno vidljivo i kroz dinamiku izrade prostorno-planske dokumentacije uglavnom za gradove Drniš i Knin u zagorskom dijelu, odnosno Šibenik i priobalna središta turističkoga razvoja. Što se tiče općinskih planova, samo je plan za općinu Drniš i 
mogao utjecati na prostorni razvoj jer je jedini bio na snazi. Planovi za općine Šibenik i Knin izrađeni su tek krajem 1980-ih i nisu stupili na snagu, zbog problema s bespravnom gradnjom, odnosno zbog početka Domovinskoga rata. Neracionalan pristup korištenju prostora vidljiv je već u razdoblju do 1990-ih: u planovima u nerazvijenim područjima građevinska zemljišta bila su nerealno planirana, dok u obalnom području nisu bila dovoljno uređena i zaštićena. Bespravna izgradnja i devastacija prostora postajala je sve veći problem, što se nastavilo u recentnom razdoblju.

Domovinski rat pridonio je daljnjem populacijskom pražnjenju velikih dijelova Županije te nanio nemjerljive štete gospodarskoj bazi. Osim toga, ovaj prostor se kao i Hrvatska u cjelini suočio s poteškoćama tranzicije društva sa sustava socijalističkih zemalja na tržišno funkcioniranje, što se odražava u novom i drugačijem vrednovanju prostora. Na državnoj i regionalnoj razini tranzicija i društveno-gospodarske promjene praćene su raspadom velikih planerskih institucija, padom interdisciplinarnosti u uređenju prostora, podlijeganju interesima kapitala i tržišta u odnosu prema prostoru. Doneseni su novi zakoni o prostornom uređenju; no, i izricane (barem načelne) težnje za uravnoteženim i policentričnim razvojem.

Novi upravno-teritorijalni ustroj trebao je djelovati suprotno od monocentričnosti bivših velikih općina, no postao je skup i glomazan aparat osobito u slučaju malih općina koje nemaju snagu pokretanja razvoja u prostoru niti financiranja svoje odrŽivosti, kakav je dio zagorskih općina u Šibensko-kninskoj županiji ${ }^{19}$. Veliki broj jedinica lokalne samouprave nosi poteškoće organizacije službi, izrade i provedbe dokumenata prostornoga uređenja, uz problem usmjerenosti na površine građevinskih područja u planovima. Na intenzitet aktivnosti u prostoru posredno ukazuje brojnost donesenih provedbenih planova u novom razdoblju: u tome prednjači Grad Šibenik, a suprotan pol čine zagorske općine.

U konačnici se može konstatirati da prostor kao resurs nije dovoljno zaštićen, što je posebno vidljivo u prevelikom zauzimanju prostora stanovima za odmor s velikim udjelom bespravne gradnje u priobalnom pojasu (apartmanizacija i betonizacija) ${ }^{20}$. Rješenja za ovaj problem nalazila su se kroz rušenje nelegalno izgrađenih objekata (primjeri u Općini Rogoznica) te legalizacijom (češće), što se dosad nije pokazalo trajno učinkovitim.

19 Broj stanovnika općina u Županiji 2011. uglavnom se kreće između 1000 i 3 500, dok vrlo malim ukupnim brojem stanovnika odskaču općine Kijevo (405) i Civljane (240 stanovnika) u kninskoj subregiji (DZS, 2011.).

20 Apartmanizacija se može definirati kao raširena, obijesna gradnja neukusnih, neprikladnih objekata za stanovanje, a betonizacija kao pretjerano, opasno, bezobzirno i/ili nezakonito betoniranje velikih razmjera (Žanić, 2004.). Ti termini, kao i pojam bespravne gradnje, često se povezuju s gradnjom marina, hotela, plaža, lokala, ali ponajviše s izgradnjom stanova za odmor (Miletić, 2006.). 


\section{Zaključak}

U radu je prikazan slijed izrade i donošenja prostornih planova za područje današnje Šibensko-kninske županije od druge polovice 20. stoljeća, te postavke planova višega reda, kroz tri osnovna razvojna razdoblja planiranja (1945. - 1975.; 1975. - 1992.; 1992. - 2012.). Obilježja planiranja na republičkoj/državnoj, (makro)regionalnoj i lokalnoj razini razmotrena su u odnosu prema dominantnim procesima u prostoru. Hrvatska općenito, njen primorski dio, a tako i Šibensko-kninska županija, ima zavidnu tradiciju planiranja i razvoja metodologije planiranja. Deklarativna težnja za optimalnim i racionalnim gospodarenjem prostorom i za zaštitom okoliša prisutna je u većini planova izrađivanih za ovo područje.

Analiza osnovnih postavki planova višega reda omogućila je i sagledavanje razvojnih procesa i struktura u prostoru na koje se izrada, donošenje i provedba planova trebala usmjeriti. Problemi u provedbi planskih postavki i koordinaciji planiranja proizlazili su iz česte statičnosti dokumenata, parcijalnoga usmjeravanja razvoja na razini velikih općina (samo jedan općinski plan bio je donesen) i nedovoljne kontrole aktivnosti u prostoru provedbenim planovima.

Pri usporedbi dinamike i drugih tekovina planiranja do 1990-ih godina i u recentnom razdoblju nema jednostavnih zaključaka jer se ovo područje suočava s nizom i naslijeđenih i novih konflikata u prostoru - od problema prevelike koncentracije stanovništva i gospodarskih funkcija u priobalnim središtima, pogodovanja parcijalnim interesima i kapitalu, prevelikoga zauzimanja prostora građevinskim područjima, te objektima sekundarnoga stanovanja s velikim udjelom bespravne gradnje u priobalnom pojasu, do nedovoljno osmišljenih razvojnih alternativa. Slabljenjem i zastarjelošću industrijske baze, pojavila se opasnost prevelike orijentacije na turističke djelatnosti te novih prostornih problema u skladu $s$ tim. Domovinski rat nanio je nemjerljive štete u društveno-gospodarskom razvoju i dodatno otežao proces tranzicije. U pogledu kvalitetnoga i održivoga prostornog planiranja i u Dubrovačko-neretvanskoj županiji, Marić (2009.) ukazuje na niz problema, primjerice sukob kapitala i održivoga razvoja, nedostatak urbanističkog planiranja s razvojnog i oblikovnog gledišta, nedostatak stalnih i kvalitetnih istraživanja i vrednovanja prostora, lošu organizaciju službi pojedinih lokalnih uprava, problem financiranja izrade i donošenja planova, način legalizacije zaostale bespravne gradnje, problem zastupljenosti i korisnosti pojedinih struka unutar prostornoga planiranja i dr.

Veliki broj jedinica lokalne samouprave u recentnom razdoblju trebao bi djelovati u smjeru kvalitetnijega vrednovanja prostornih resursa u odnosu na bivše velike općine koje je uvelike karakterizirao monocentrični razvoj (vidljiv i po dinamici izrade provedbenih planova). Međutim, veliki partikularizam također nosi opasnosti neracionalnoga korištenja i parcijalnoga poimanja prostora. Hrvatin i Grgurević (2007.) na primjeru zapadne Istre upozoravaju na probleme nedostatka koordinacije jedinica lokalne samouprave i usklađivanja osnovnih parametara i planskih rješenja te opasnost odstupanja od tradicije kvalitetnoga planiranja. 
Istraživanje je pokazalo da se Šibensko-kninska županija treba dalje učinkovitije nositi s nizom prostorno-razvojnih dispariteta. Pritom bi važan mehanizam trebalo biti sustavno planiranje koje će integralno promatrati prostor, a koordinacija planiranja i usmjeravanja procesa u prostoru trebala bi se jače odvijati na makroregionalnoj i regionalnoj razini. Preduvjet održivoga prostornog razvoja jačanje je prostorno-planskih službi i institucija, među ostalim stručnjacima različitih disciplina, kvalitetna izrada prostorno-planske dokumentacije interdisciplinarnom suradnjom, i nadasve primjena planskih postavki strožim mehanizmima nadzora i sankcija.

\section{Literatura i izvori}

1. Defilippis, J. (2006). Promjene u poljoprivredi i selu Dalmacije u posljednjih stotinjak godina. Društvena istraživanja, 15 (6): 1047-1062.

2. Detaljni plan Šibenik-Srima, Projekt Gornji Jadran (1971). Split: Shankland Cox and Associates i Urbanistički zavod Dalmacije.

3. Državni zavod za statistiku (2001). Popis stanovništva, kućanstava i stanova 31. ožujka 2001., Stanouništvo prema spolu i starosti po naseljima. Pregledano 12. kolovoza 2010. (www.dzs.hr).

4. Državni zavod za statistiku (2011). Popis stanovništva, kućanstava i stanova 2011., Prvi rezultati po naseljima, Statistička izvješća 1441. Pregledano 26. kolovoza 2011. (www.dzs.hr).

5. Faričić, J.; Graovac, V. i Čuka, A. (2010). Mali hrvatski otoci - radno-rezidencijalni prostor i/ili prostor odmora i rekreacije. Geoadria, 15 (1): 145-185.

6. Friganović, M. (1974). Šibenska regija, u: Cvitanović, Alfonso (Ur.). Geografija SR Hrvatske, Južno Hrvatsko primorje. Zagreb: Školska knjiga.

7. Friganović, M. (1992). Demografska osnova i razvoj šibenske regije. Acta Geographica Croatica, 27: 1-14.

8. Grad Šibenik, Upravni odjel za provedbu dokumenata prostornog uređenja i gradnju, Prostorni planovi na snazi. Pregledano 28. listopada 2009. (http:// www.sibenik.hr/upravni odjeli/provedba3.asp).

9. Hrvatin, D. i Grgurević, O. (2007). Kontinuitet procesa izrade prostornih planova na području zapadne Istre. Prostor: znanstveni časopis za arbitekturu $i$ urbanizam, 15 (2/34/): 250-259.

10. Koordinacioni prostorni plan Dalmacije: snimak stanja urbanističkib službi $i$ urbanističke dokumentacije na području Zajednice općina Split (knjiga 2) (1976). Split: Urbanistički zavod Dalmacije.

11. Koordinacioni prostorni plan Dalmacije: vrednovanje i ocjena urbanističkoplanske dokumentacije na području Dalmacije (knjiga 3) (1977). Split: Urbanistički zavod Dalmacije.

12. Koordinacioni regionalni prostorni plan Gornjeg Jadrana: završni izvještaj (1972). Rijeka: Urbanistički institut SR Hrvatske i Urbanistični inštitut SR Slovenije.

13. Kranjčević, J. (2002). Pregled prostornih planova sela u Hrvatskoj od sredine 19. do sredine 20. stoljeća. Zagreb: Ministarstvo zaštite okoliša i prostornog uređenja Republike Hrvatske. 
14. Kranjčević, J. (2005). Proces pridruživanja Europskoj uniji i prostorno uređenje Hrvatske, u: Ott, K. (Ur.). Pridruživanje Hrvatske Europskoj uniji: Ususret izazovima pregovora, Treći svezak. Zagreb: Institut za javne financije i Zaklada Friedrich Ebert.

15. Lučev, D. (2001). Iskustva pri izradi Prostornog plana Šibensko-kninske županije sa posebnim osvrtom na pitanja zaštite okoliša. Gospodarstvo i okoliš, 9 (50): 254-255.

16. Magaš, D. (2000). Suvremeni problemi prostornog razvoja Hrvatske, u: Pejnović D. (Ur.). 2. hrvatski geografski kongres: zbornik radova. Zagreb: Hrvatsko geografsko društvo.

17. Marić, J. (2009). Prostorno planiranje u Dubrovačko-neretvanskoj županiji. Geoadria, 14 (1): 87-140.

18. Marinović-Uzelac, A. (2001). Prostorno planiranje. Zagreb: Dom i svijet.

19. Mattioni, V. (2003). Jadranski projekti: projekti Južnog i Gornjeg Jadrana 1967. - 1972. Zagreb: Urbanistički institut Hrvatske.

20. Miletić, G.-M., (2006). Stavovi lokalne javnosti o nekim socijalno-ekologijskim posljedicama izgradnje stanova za odmor na otoku Viru. Društvena istraživanja, 5 (1-2): 43-60.

21. Nejašmić, I. (1991). Depopulacija u Hrvatskoj: korijeni, stanje, izgledi. Zagreb: Globus.

22. Odluka o općinama koje mogu donijeti prostorni plan uređenja općine sa smanjenim sadržajem, Narodne novine 163 od 2004.

23. Opačić, V. T. (2009). Recent Characteristics of the Second Home Phenomenon in the Croatian Littoral. Hrvatski geografski glasnik, 71 (1): 33-66.

24. Općina Drniš, Osnova korištenja i zaštite prostora: grafički prilozi (1993). Zagreb: Urbanistički institut Hrvatske, Zavod za prostorno planiranje.

25. Općina Knin, Osnova korištenja i zaštite prostora (1993). Zagreb: Urbanistički institut Hrvatske, Zavod za prostorno planiranje.

26. Općina Šibenik, Osnova korištenja i zaštite prostora (1993). Zagreb: Urbanistički institut Hrvatske, Zavod za prostorno planiranje.

27. Planerski atlas SR Hrvatske (1974). Zagreb: Republički sekretarijat za urbanizam, građevinarstvo, stambene i komunalne poslove.

28. Poljičak, I. (1995). Šibenik na razmeđu: socijalnoekologijski ogled. Šibenik: Gradska knjižnica "Juraj Šišgorić".

29. Pravilnik o općinama koje mogu donijeti prostorni plan uređenja općine smanjenog sadržaja i sadržaju, mjerilima kartografskih prikaza i obveznim prilozima toga plana, Narodne novine 135 od 2010.

30. Program dugoročnog razvoja i plan prostornog uređenja Jadranskog područja: Dugoročna projekcija stanovništva (1967). Zagreb: Urbanistički institut SR Hrvatske.

31. Program mjera za unapređenje stanja u prostoru, Izvješće o stanju u prostoru, Gradsko vijeće Grada Šibenika, Službeni vjesnik Županije Šibenske 04 od 1995. Pregledano 10. studenog 2009. (http://www.sibensko-kninska-zupanija.hr/svskz/1995/04.pdf).

32. Program prostornog uređenja Republike Hrvatske (1999). Zagreb: Ministarstvo prostornog uređenja, graditeljstva i stanovanja, Zavod za prostorno planiranje. 
33. Prostorni plan općine Knin (1989). Zagreb: Urbanistički institut SR Hrvatske.

34. Prostorni plan općine Šibenik (1990). Zagreb: Urbanistički institut SR Hrvatske.

35. Prostorni plan Šibensko-kninske županije, Knjiga 1 (2002). Šibenik: Županijski zavod za prostorno uređenje Šibensko-kninske županije i Urbing d.o.o. za poslove prostornog uređenja i zaštite okoliša.

36. Prostorni plan Šibensko-kninske županije, Knjiga 2 - Odredbe za provođenje (pročišćeni tekst) (2007). Šibenik: Županijski zavod za prostorno uređenje Šibensko-kninske županije i Urbing d.o.o. za poslove prostornog uređenja i zaštite okoliša.

37. Prostorni plan SR Hrvatske godina 2000: završni izvještaj (1974). Zagreb: Republički sekretarijat za urbanizam, građevinarstvo, stambene i komunalne poslove SR Hrvatske.

38. Prostorni plan SRH. Narodne novine, 12 od 1989.

39. Službeni glasnici Grada Šibenika 2008.-2012. Pregledano između listopada 2009. i studenog 2012. (http://www.sibenik.hr/glasnik/index.asp).

40. Službeni vjesnici općine Drniš, Knin i Šibenik 1963.-1973.

41. Službeni vjesnici Šibensko-kninske županije 2007.-2012. Pregledano između listopada 2009. i studenog 2012. (http://www.sibensko-kninska-zupanija.hr/svskz/).

42. Statut grada Skradina (2002). Zagreb - Skradin: Matica hrvatska Skradin.

43. Strategija prostornog uređenja Republike Hrvatske (1997.). Zagreb: Ministarstvo prostornog uređenja, graditeljstva i stanovanja, Zavod za prostorno planiranje.

44. Šimunović, I. (1982). Prostorni plan Zajednice općina Split do 2000. godine: sažetak. Zajednica općina Split.

45. Šprljan, I. (1997). Sjećanje na sretan graditeljski početak. Čovjek i prostor, 44 (3-4): 56-57.

46. Vresk, M. (1990). Grad u regionalnom i urbanom planiranju. Zagreb: Školska knjiga.

47. Zaključak o prihvaćanju Izvješća o stanju u prostoru i Programa mjera za unapređenje stanja u prostoru, Gradsko vijeće Grada Drniša. Službeni vjesnik Šibensko-kninske županije, 01 od 2000. Pregledano 02. listopada 2009. (http://www. sibensko-kninska-zupanija.hr/svskz/2000/01.pdf).

48. Zaključak o prihvaćanju Izvješća o stanju u prostoru i Programa mjera za unapređenje stanja u prostoru, Županijska skupština Županije šibenske. Službeni vjesnik Županije šibenske, 04 od 1996. Pregledano 16. listopada 2009. (http:// www.sibensko-kninska-zupanija.hr/svskz/1996/04.pdf).

49. Zaključak o prihvaćanju Izvješća o stanju u prostoru i Programa mjera za unapređenje stanja u prostoru Šibensko-kninske županije, Županijska skupština Šibensko-kninske županije. Službeni vjesnik Šibensko-kninske županije, 03 od 1999. Pregledano 16. listopada 2009. (http://www.sibensko-kninska-zupanija. hr/svskz/1999/03.pdf).

50. Zaključak o prihvaćanju Izvješća o stanju u prostoru i Programa mjera za unapređenje stanja u prostoru Šibensko-kninske županije, Županijska skupština Šibensko-kninske županije. Službeni vjesnik Šibensko-kninske županije, 02 od 2007. Pregledano 16. listopada 2009. (http://www.sibensko-kninska-zupanija. hr/svskz/2007/02.pdf). 
51. Zaključak o usvajanju Izvješća o stanju u prostoru Grada Knina i donošenju Programa mjera za unapređenje stanja u prostoru Grada Knina, Gradsko vijeće Grada Knina. Službeni vjesnik Šibensko-kninske županije, 02 od 1998. Pregledano 11. studenoga 2009. (http://www.sibensko-kninska-zupanija.hr/svskz/1998/02. pdf).

52. Zakon o urbanističkom i regionalnom prostornom planiranju. Narodne novine, 21 od 1961.

53. Zakon o urbanističkom i regionalnom prostornom planiranju (prečišćeni tekst). Narodne novine, 39 od 1966.

54. Zakon o izmjenama i dopunama Zakona o urbanističkom i regionalnom prostornom planiranju. Narodne novine, 18 od 1969.

55. Zakon o područjima županija, gradova i općina u Republici Hrvatskoj. Narodne novine, 86 od 2006.

56. Zakon o prostornom uređenju i korištenju građevinskog zemljišta. Narodne novine, 14 od 1973.

57. Zakon o prostornom planiranju i uređivanju prostora. Narodne novine, 54 od 1980.

58. Zakon o izmjenama i dopunama Zakona o prostornom planiranju i uređivanju prostora. Narodne novine, 16 od 1986.

59. Zakon o prostornom uređenju. Narodne novine, 30 od 1994.

60. Zakon o izmjenama i dopunama Zakona o prostornom uređenju. Narodne novine, 68 od 1998.

61. Zakon o prostornom uređenju i gradnji. Narodne novine, 76 od 2007.

62. Zelić, D. (1995). Gradski statut kao izvor za povijest urbanog razvoja Šibenika. Radovi Instituta za povijest umjetnosti, 19: 37-51.

63. Žanić, I. (2004). Nove stvarnosti i njihovi akteri. Kako i zašto nastaju riječi i tko je za to "kriv". Politička misao, 41 (1): 74-91. 


\title{
Spatial Planning in the Area of Šibenik-Knin County Since the Second Half of the 20th Century
}

\begin{abstract}
Reconsidering the efficiency of contemporary spatial planning in Croatia and comparing it with the legacy passed on since the second half of the 20th century which has influenced its shaping, this paper deals with the development of spatial planning for the area of ŠibenikKnin County (organised as a regional self-government unit in 1997.). In accordance with the available sources the sequence of plan making and adoption was reconstructed within three periods of time and higher level planning guidelines were analysed. The first period lasted until the mid 1970s when the first country spatial plan was adopted. The second period lasted until 1992.; towards the end of that period the second country spatial plan was adopted. Following the Croatian independence the new territorial organisation was implemented, thus beginning the third period. Within each period three levels of spatial planning can be recognized: macro (national), mezzo (macro-regional and regional) and micro (local) level. The main guidelines concerning spatial development issues are shown for the analysed spatial plans.

In spite of aspiring to optimal and rational development and environmental protection in spatial plans, Šibenik-Knin County is facing many inherited and new conflicts in space: overconcentration of population and economic activities in coastal settlements, favouring partial interests and capital, zones of excessive construction work and building of second homes, lots of illegal construction work, lack of effective development alternatives. An important mechanism for dealing with spatial development disparities is systematic planning. Careful coordination of planning on the (macro)regional level is also needed. A precondition of sustainable spatial development is that planning authorities and institutes should be reinforced by interdisciplinary teams. A further requirement are high quality spatial planning documents, a strict supervision of their implementation and a strict system of penalties.
\end{abstract}

Key words: spatial planning, spatial planning documents, spatial development disparities, Šibenik-Knin County, Adriatic Croatia. 